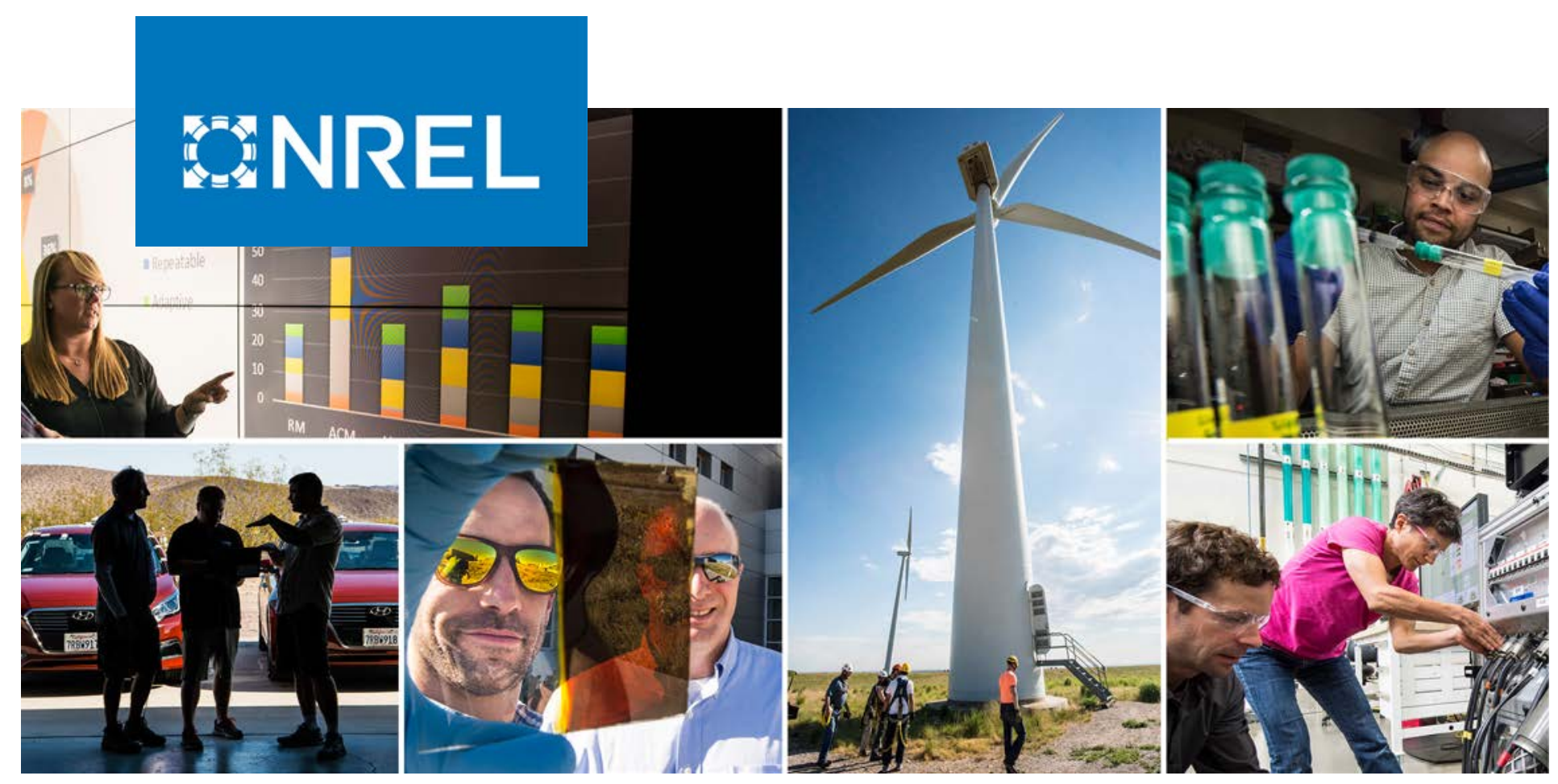

\title{
A Survey of Federal and State-Level Solar System Decommissioning Policies in the United States
}

Taylor L. Curtis, Ligia E.P. Smith, Heather Buchanan, and Garvin Heath

National Renewable Energy Laboratory

NREL is a national laboratory of the U.S. Department of Energy

Office of Energy Efficiency \& Renewable Energy

Operated by the Alliance for Sustainable Energy, LLC

This report is available at no cost from the National Renewable Energy Laboratory (NREL) at www.nrel.gov/publications.
Technical Report

NREL/TP-6A20-79650

December 2021 


\title{
GNREL
}

\section{A Survey of Federal and State-Level Solar System Decommissioning Policies in the United States}

\author{
Taylor L. Curtis, Ligia E.P. Smith, Heather Buchanan, \\ and Garvin Heath
}

National Renewable Energy Laboratory

\section{Suggested Citation}

Curtis, Taylor L., Ligia E.P. Smith, Heather Buchanan, and Garvin Heath. 2021. Survey of Federal and State-Level Solar System Decommissioning Policies in the United States. Golden, CO: National Renewable Energy Laboratory. NREL/TP-6A20-79650.

https://www.nrel.gov/docs/fy22osti/79650.pdf

NREL is a national laboratory of the U.S. Department of Energy Office of Energy Efficiency \& Renewable Energy Operated by the Alliance for Sustainable Energy, LLC

This report is available at no cost from the National Renewable Energy Laboratory (NREL) at www.nrel.gov/publications.

Contract No. DE-AC36-08GO28308
Technical Report

NREL/TP-6A20-79650

December 2021

National Renewable Energy Laboratory 15013 Denver West Parkway Golden, CO 80401

303-275-3000 • www.nrel.gov 


\section{NOTICE}

This work was authored by the National Renewable Energy Laboratory, operated by Alliance for Sustainable Energy, LLC, for the U.S. Department of Energy (DOE) under Contract No. DE-AC36-08G028308. Funding provided by the U.S. Department of Energy Office of Energy Efficiency and Renewable Energy Solar Energy Technologies Office. The views expressed herein do not necessarily represent the views of the DOE or the U.S. Government.

This report is available at no cost from the National Renewable Energy Laboratory (NREL) at www.nrel.gov/publications.

U.S. Department of Energy (DOE) reports produced after 1991 and a growing number of pre-1991 documents are available free via www.OSTI.gov.

Cover Photos by Dennis Schroeder: (clockwise, left to right) NREL 51934, NREL 45897, NREL 42160, NREL 45891, NREL 48097, NREL 46526.

NREL prints on paper that contains recycled content. 


\section{Acknowledgments}

We gratefully acknowledge the Department of Energy's Solar Energy Technologies Office for its funding support. We also thank the following report reviewers for their time and expertise: Kristen Ardani, Jesse Carey, Megan Day, and Mike Meshek (editor), National Renewable Energy Laboratory; Parikhit Sinha, First Solar; Cara Libby, Electric Power Research Institute; and Jennifer Martin, Illinois Sustainable Technology Center. 


\section{List of Acronyms}

$\begin{array}{ll}\text { AESL } & \text { Alternative Energy Source Lease } \\ \text { BLM } & \text { Bureau of Land Management } \\ \text { BOS } & \text { Balance-of-system } \\ \text { CSP } & \text { Concentrated Solar Power } \\ \text { EoL } & \text { End-of-life } \\ \text { FLPMA } & \text { Federal Land Policy and Management Act } \\ \text { FS } & \text { Forest Service } \\ \text { FWS } & \text { U.S. Fish and Wildlife Service } \\ \text { GW } & \text { Gigawatt } \\ \text { kW } & \text { Kilowatt } \\ \text { MW } & \text { Megawatt } \\ \text { NPS } & \text { National Park Service } \\ \text { NREL } & \text { National Renewable Energy Laboratory } \\ \text { PSC } & \text { Public Service Commission } \\ \text { PUC } & \text { Public Utilities Commission } \\ \text { PV } & \text { Photovoltaic } \\ \text { PV ICE } & \text { PV in the Circular Economy } \\ \text { RCE } & \text { Reclamation Cost Estimate } \\ \text { ROW } & \text { Right-of-way }\end{array}$




\section{Executive Summary}

In the United States, cumulative installed utility-scale solar photovoltaic (PV) capacity reached more than 60 gigawatts $(\mathrm{GW}) \mathrm{dc}$ at the end of 2020 (Davis et al. 2021b). Federal and state renewable energy and net-zero emissions policies will continue to drive solar development in the United States with installed utility-scale PV projected to quadruple ( $240 \mathrm{GW}_{\mathrm{dc}}$ ) by 2030 (Davis et al. 2021a; Heeter 2014).

Although more than $75 \%$ of all U.S. installed utility-scale PV came online in the last 5 years, federal, state, and local governments are planning for system decommissioning (Davis et al. 2021b). Our research found that as of April 2021, one federal agency, the Bureau of Land Management (BLM), and 15 U.S. states have solar decommissioning policies in place. North Carolina is also in the process of drafting solar decommissioning regulations, and at least 4 states (Maine, Pennsylvania, West Virginia, Texas) proposed solar decommissioning bills in the 2021 legislative session. ${ }^{1}$

Decommissioning a PV system typically includes removing the PV array; removing all balance-ofsystem (BOS) equipment (i.e., other parts of the PV system, excluding modules, which can include wiring, inverters, and the mounting system); and restoring the land or infrastructure (e.g., roofs and irrigation canals) to its original condition or for a new use (Curtis et al. 2021a; Barbosa 2020).

Federal and state solar decommissioning policies ${ }^{2}$ in the United States typically apply to utilityscale projects and mandate compliance with regulatory requirements over the lifetime of the project (not only during system decommissioning). Most U.S. solar decommissioning policies are tied to a permit or approval required for initial project development - typically as a condition or term of the approval. Some jurisdictions require a decommissioning cost estimate and/or the submission of a decommissioning plan prior to project construction. Solar decommissioning policies may also require a financial assurance for decommissioning, and compliance with reporting and records requirements over the lifetime of the project. Most decommissioning policies also require compliance with specific performance activities, including removal of all solar system equipment, site restoration, and reclamation (e.g., soil regrading, revegetation, reseeding, removal of access roads). A project owner may also be subject to civil penalties for noncompliance under some U.S. state solar decommissioning policies.

A calculation using the National Renewable Energy Laboratory's (NREL) PV in the Circular Economy (PViCE) tool predicts at least $27 \mathrm{GW}$ of all nonresidential (commercial and utility-scale) PV capacity installed as of 2020 will be decommissioned in the U.S. by 2030 (Ayala et al. 2021). ${ }^{3}$

12019 N.C. Sess. Laws 132, S.P. 113, 130th Leg., Reg. Sess. (Me. 2021), H.B. 1555, 205th Gen. Assemb., Reg. Sess. (Pa. 2021), S.B. 492, 2021 Leg., Reg. Sess. (W. Va. 2021), S.B. 760, 2021 Leg., Reg. Sess. (Tex. 2021).

${ }^{2}$ We use "policy" in this report broadly to include not only mandated federal and state regulatory and legal requirements but also guidance, programs, and initiatives.

${ }^{3}$ The PViCE calculation only considers known nonresidential (commercial and utility-scale) installations of crystalline silicon PV through 2020; thin film is excluded, and no estimates of future installations are made. PV module technology evolutions and dynamic lifetime assumptions are drawn from data derived PViCE baselines (Ovaitt et al. forthcoming). This analysis can be explored in the Jupyter Journal "14 - Historical US Installs Waste Projection" on the PViCE GitHub. 
Solar decommissioning policies in the United States vary by federal, state, and local jurisdiction. The BLM requires a solar facility right-of-way (ROW) holder to submit a decommissioning plan and proof of financial security to support decommissioning costs. Fifteen states have also enacted statewide decommissioning policies that require solar developers to comply with specific decommissioning performance activities, submit decommissioning plans, estimate costs of decommissioning, and/or provide proof of financial assurance to state and/or local jurisdictions. The remaining 35 states and the District of Columbia leave solar decommissioning policies completely to local governments. Of those 35 states, 9 states ${ }^{4}$ have model ordinances, templates, or other resources that local governments may — but are not required - to use in developing their local solar decommissioning policies. Table ES-1 provides an overview of federal and statewide solar decommissioning policies in the United States.

The 15 states with statewide solar decommissioning policies have diverse regulatory frameworks that vary by jurisdiction. Six states (Louisiana, Minnesota, Montana, New Hampshire, North Dakota, and Vermont) have enacted state-level policies that require solar project owners to submit decommissioning plans and proof of financial assurance. Eight states (California, Hawaii, Illinois, Nebraska, New Jersey, Oklahoma, Virginia, and Wyoming) have enacted hybrid state and local solar decommissioning policies. In states with hybrid policies, localities must follow state decommissioning requirements enacted through statute and/or regulation but may prescribe additional requirements, which in some cases are more stringent than the state requirements. Washington state has an optional statewide solar decommissioning program, which allows solar project owners to comply with a state certification process in lieu of obtaining local city and county government approvals. In addition to jurisdictional mandates, a landowner may also prescribe additional solar decommissioning requirements (e.g., site restoration and reclamation) as a condition to a land or building lease agreement for a solar facility located on private land (Pivot Energy 2017).

Table ES-1. Federal and State Solar Decommissioning Policies in the United States: Selected Attributes

\begin{tabular}{|l|c|c|}
\hline Jurisdiction & $\begin{array}{l}\text { Decommissioning Plan } \\
\text { Required by Federal or State } \\
\text { Policy }\end{array}$ & $\begin{array}{l}\text { Financial Assurance Required } \\
\text { by Federal or State Policy }\end{array}$ \\
\hline Federal & \multicolumn{2}{|c|}{ Yes } \\
\hline BLM & \multicolumn{2}{|l|}{ Yes } \\
\hline State-Level Only & Yes & Yes \\
\hline Louisiana & Yes & Yes \\
\hline Minnesota & Yes & Yes \\
\hline Montana & Yes & Yes \\
\hline New Hampshire & Yes & Yes \\
\hline North Dakota & Yes & Yes \\
\hline Vermont &
\end{tabular}

${ }^{4}$ Georgia, Iowa, Massachusetts, New York, North Carolina, Oregon, Rhode Island, Texas, Wisconsin 


\begin{tabular}{|l|c|c|}
\hline Jurisdiction & $\begin{array}{l}\text { Decommissioning Plan } \\
\text { Required by Federal or State } \\
\text { Policy }\end{array}$ & $\begin{array}{l}\text { Financial Assurance Required } \\
\text { by Federal or State Policy }\end{array}$ \\
\hline Hybrid State/Local & Yes \\
\hline California & No & Yes \\
\hline Hawaii & Yes & Yes \\
\hline Illinois & No & Yes \\
\hline Nebraska ${ }^{5}$ & Yes \\
\hline New Jersey & No & No \\
\hline Oklahoma & No \\
\hline Virginia & Yes & Yes \\
\hline Wyoming & Yes & No \\
\hline State-Level/Optional & & Yes \\
\hline Washington & Yes & \multicolumn{2}{|c|}{} \\
\hline
\end{tabular}

We found that BLM and 12 of the 15 state policies in the United States tie their decommissioning requirements to an approval required for initial project development (e.g., site license, right-of-way). These jurisdictions require a solar project developer submit a decommissioning plan and/or proof of financial assurance as a pre-requisite or condition of approval needed for project construction or operation. We also found that BLM and 11 of the 15 statewide solar decommissioning policies in the United States require owners to issue a financial assurance instrument (e.g., bond, guarantee, or escrow fund) to cover the cost of system decommissioning prior to project construction or at some point in time after project operation (Maamari 2018; NYSERDA 2020). ${ }^{7}$

Anecdotal evidence suggests that compliance with decommissioning policies can impact utilityscale solar project construction timelines, project economics, and overall project viability (Maamari 2018; NYSERDA 2020). ${ }^{8}$ For example, jurisdictions that require submission of decommissioning plans and/or financial assurance as a pre-requisite or condition of approval prior to project construction or operation can impact construction timelines and capital costs associated with project development (Wyatt 2020). ${ }^{9}$ Policies that require financial assurance at

\footnotetext{
${ }^{5}$ In Nebraska, there is a state-level solar decommissioning policy in place; however, the state does not require a decommissioning plan or financial assurance, but delegates authority to local government which may prescribe decommissioning requirements including a decommissioning plan and/or financial assurance.

${ }^{6}$ In Oklahoma, there is a state-level solar decommissioning policy in place; however, the state does not require a decommissioning plan or financial assurance, but delegates authority to local government which may prescribe decommissioning requirements including a decommissioning plan and/or financial assurance.

${ }^{7}$ Mont. Admin. R. 17.86.102, 106, 115; Vt. PUC Rule 5.904; La. Admin. Code tit. 43:V, §§ 953, 955; Minn. R. 7854.0500; N.H. Admin. R. Site 301.08(d)(2).

${ }^{8}$ Megan Day, National Renewable Energy Laboratory, email, October 19, 2020.

${ }^{9}$ The Bureau of Land Management (BLM) as well as several states including Hawaii, California, Louisiana, Montana, New Hampshire, Louisiana, Minnesota, North Dakota, Wyoming, and Vermont require compliance with decommissioning policies as a condition of approval prior to solar project construction or operation. In addition, Virginia's policy requires localities to tie site license approval for solar facilities to decommissioning requirements.
} 
the outset of a project prior to construction or operation ${ }^{10}$ (e.g., Louisiana, Vermont) increase capital costs, which may prolong construction timelines and discourage project development (NYSERDA 2020). By contrast, policies that allow project owners to use an incremental bond schedule (e.g., North Dakota, Illinois) or issue financial assurance after project operations (e.g., Montana) allow financial assurance to be incurred as an operating cost rather than a capital cost.

Moreover, the calculation method and/or amount of financial assurance mandated by solar decommissioning policies varies by jurisdiction and may raise or lower overall project costs depending on what the policy includes. For example, policies that mandate that financial assurance amounts include site restoration and reclamation costs to return land to its preconstruction condition (e.g., Vermont) may raise costs of decommissioning depending on the size of the facility and the preconstruction uses of the land. By contrast, some solar decommissioning policies allow facility owners to offset the costs of decommissioning with the estimated salvage value of the facility equipment (e.g., Montana), which may lower overall project costs.

Solar decommissioning policies can also impact project operations, solar equipment end-of-life (EoL) management decisions, and system repowering evaluations. For example, some state solar decommissioning policies mandate compliance with reporting and records keeping requirements during project operation. Solar decommissioning policies may also impact equipment retirement and EoL decisions by requiring project owners to submit plans and detailed cost estimates accounting for transportation, salvage (e.g., reuse, recycling), and/or disposal of decommissioned system equipment (Maamari 2018; NYSERDA 2020).

This report provides a survey and brief overview of both BLM and U.S. statewide solar decommissioning policies, and a discussion of some of the potential impacts different policy designs may have on utility-scale solar development, including impacts that might influence construction timelines and over project costs.

Our results are based on legal and literature-based research, as well as a 50-state survey to identify enacted statewide solar decommissioning policies. We also conducted a survey of the four major federal land management agencies (BLM, Forest Service, Fish and Wildlife Service, and National Park Service) and determined that BLM is currently the only major federal land management agency with a solar decommissioning policy. Accordingly, our analysis of federal decommissioning policies is limited to BLM. Decommissioning policies developed by other federal agencies, which may have solar installations on property or land under their jurisdiction (e.g., the Department of Defense, the Bureau of Indian Affairs) were not addressed within this report. Local and municipal ordinances addressing solar decommissioning requirements are also outside the scope of this report. In addition, this report does not provide an in-depth analysis or comparison of cost-estimate calculations by jurisdiction or the impacts solar decommissioning requirements, such as financial assurance instruments, have on solar project development, project operations, EoL equipment management decisions, or system repowering evaluations.

\footnotetext{
${ }^{10}$ New Hampshire, Minnesota, Vermont, Louisiana, California, Hawaii, and Virginia all require proof of financial assurance prior to solar project construction or operation.
} 


\section{Table of Contents}

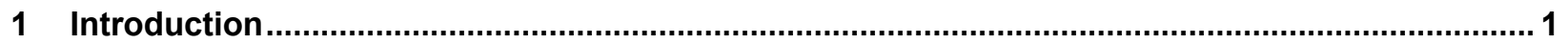

2 Bureau of Land Management Solar Decommissioning Policy ....................................................6

3 States with Mandatory State-Level Solar Decommissioning Policies ......................................... 9

3.1 State-Level Solar Decommissioning Plan Requirements................................................... 11

3.2 State-level Solar Decommissioning Financial Assurance Requirements................................. 14

3.3 State-level Solar Decommissioning Policies Oversight Authority and Penalties ...................... 16

4 States with Hybrid State/Local Solar Decommissioning Policies ............................................ 18

4.1 Hybrid State/Local Solar Decommissioning Plan and/or Performance Requirements ............... 21

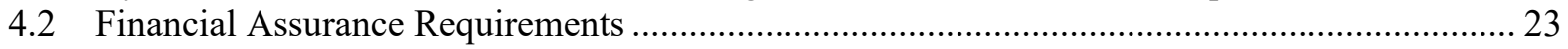

4.3 Hybrid State/Local Solar Decommissioning Policies Oversight Authority and Penalties .......... 26

5 Optional State-level Decommissioning Requirements in Washington....................................... 27

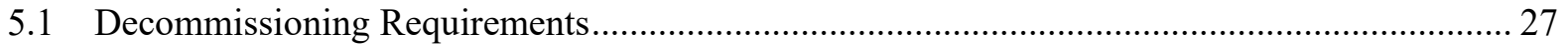

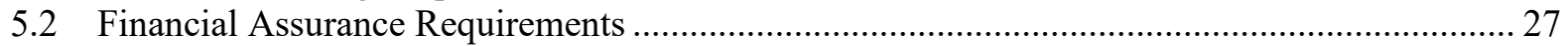

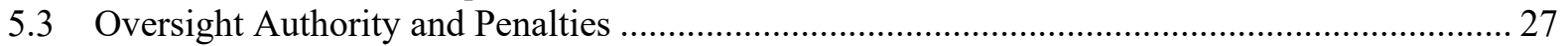

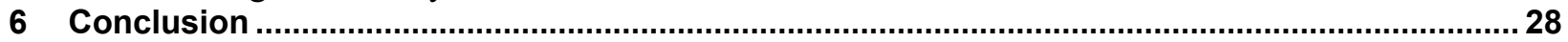

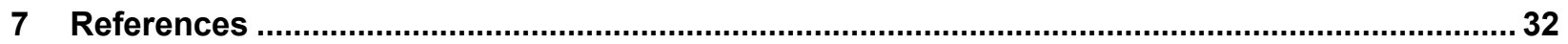

7.1 Federal and State Statutes and Legislative Materials ......................................................... 34

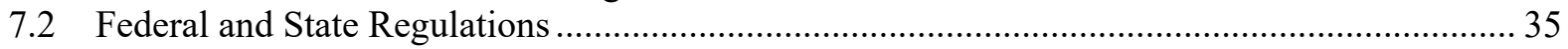

\section{List of Figures}

Figure 1. Map of state solar decommissioning policies in the United States........................................... 3

Figure 2. Map of state solar decommissioning financial assurance policies in the United States ............... 5

\section{List of Tables}

Table ES-1. Federal and State Solar Decommissioning Policies in the United States .............................. vi

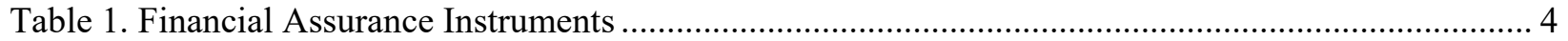

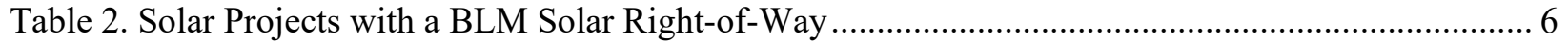

Table 3. Pending Construction - Solar Projects with a BLM Solar Right-of-Way .................................... 8

Table 4. Regulatory Threshold for State-Level Solar Decommissioning Policies and Summary of

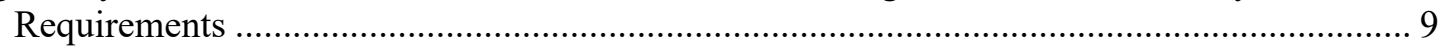

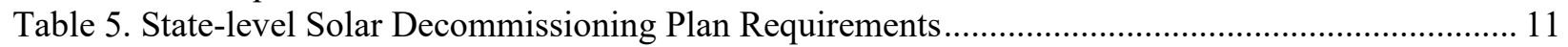

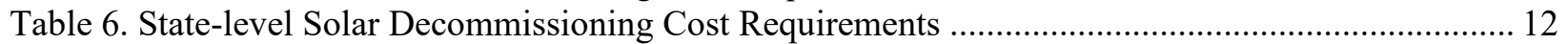

Table 7. State-level Solar Decommissioning Financial Assurance Requirements ................................... 14

Table 8. State-level Solar Decommissioning Policies Oversight Authority and Penalties ........................ 16

Table 9. Regulatory Threshold for Hybrid State/Local Solar Decommissioning Policies and Summary of

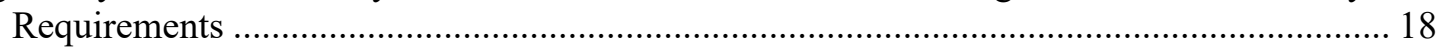

Table 10. Hybrid State/Local Solar Decommissioning Plan and Performance Requirements ................... 21

Table 11. Hybrid State/Local Solar Decommissioning Cost Requirements ............................................ 22

Table 12. Hybrid State/Local Financial Assurance Requirements .................................................... 23

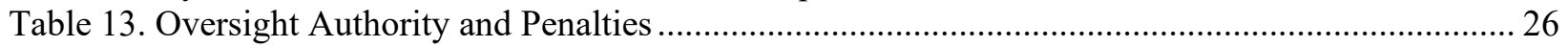

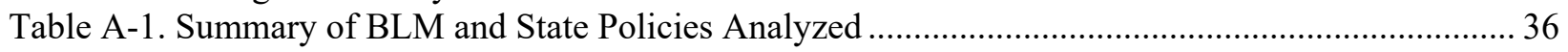

Table A-2. Solar projects with a BLM Right-of-Way ....................................................................... 44 


\section{Introduction}

In the United States, cumulative installed utility-scale solar photovoltaic (PV) capacity reached more than 60 gigawatts $(\mathrm{GW}) \mathrm{dc}$ at the end of 2020 (Davis et al. 2021b). Federal and state renewable energy and net-zero emissions policies will continue to drive solar development in the United States with installed utility-scale PV projected to quadruple (240 $\mathrm{GW}_{\mathrm{dc}}$ ) by 2030 (Davis et al. 2021a; Heeter 2014).

Although more than $75 \%$ of all U.S. installed utility-scale PV came online in the last 5 years, federal, state, and local governments are planning for system decommissioning (Davis et al. 2021b). Our research found that as of April 2021, one federal agency, the Bureau of Land Management (BLM), and 15 U.S. states have solar decommissioning policies in place. North Carolina is also in the process of drafting solar decommissioning regulations, and at least 4 states (Maine, Pennsylvania, West Virginia, Texas) proposed solar decommissioning bills in the 2021 legislative session. ${ }^{11}$

Decommissioning a PV system typically includes removing the PV array; removing all balance-ofsystem (BOS) equipment (i.e., other parts of the PV system, excluding modules, which can include wiring, inverters, and the mounting system); and restoring the land or infrastructure (e.g., roofs and irrigation canals) to its original condition or for a new use (Curtis et al. 2021a; Barbosa 2020).

Legislative momentum for solar decommissioning policies in the United States is expected to continue as system assets age, extreme weather events become more prevalent, and large-scale PV deployment increases. A calculation using the National Renewable Energy Laboratory's (NREL) PV in the Circular Economy (PViCE) tool predicts approximately $27 \mathrm{GW}$ of all nonresidential (commercial and utility-scale) PV capacity installed as of 2020 will be decommissioned in the U.S. by 2030 (Ayala et al. 2021). ${ }^{12}$

Federal and state solar decommissioning policies ${ }^{13}$ in the United States typically apply to utilityscale projects and mandate compliance with regulatory requirements over the lifetime of the project (not only during system decommissioning). Most U.S. solar decommissioning policies are tied to a permit or approval required for initial project development - typically as a condition or term of the approval. Some jurisdictions require a decommissioning cost estimate and/or the submission of a decommissioning plan prior to project construction. Solar decommissioning policies may also require financial assurance for decommissioning, and compliance with reporting and records requirements over the lifetime of the project. Most decommissioning policies also require compliance with specific performance activities, including removal of all

112019 N.C. Sess. Laws 132, S.P. 113, 130th Leg., Reg. Sess. (Me. 2021), H.B. 1555, 205th Gen. Assemb., Reg. Sess. (Pa. 2021), S.B. 492, 2021 Leg., Reg. Sess. (W. Va. 2021), S.B. 760, 2021 Leg., Reg. Sess. (Tex. 2021).

${ }_{12}$ The PViCE analysis only considers known installations of nonresidential (commercial and utility-scale) crystalline silicon PV through 2020; thin film is excluded, and no estimates of future installations are made. PV module technology evolutions and dynamic lifetime assumptions are drawn from data derived PViCE baselines (Ovaitt et al. forthcoming). This analysis can be explored in the Jupyter Journal "14 - Historical US Installs Waste Projection" on the PViCE GitHub.

${ }^{13}$ We use "policy" in this report broadly to include not only mandated federal and state regulatory and legal requirements but also guidance, programs, and initiatives. 
solar system equipment, site restoration, and reclamation (e.g., soil regrading, revegetation, reseeding, removal of access roads). A project owner may also be subject to civil penalties for noncompliance under some U.S. state solar decommissioning policies.

Solar decommissioning policies in the United States vary by federal, state, and local jurisdiction. The BLM requires a solar facility right-of-way (ROW) holder ${ }^{14}$ to submit a decommissioning plan and proof of financial security to support decommissioning costs. Fifteen states have also enacted statewide decommissioning policies with varying requirements that may mandate solar facility developers comply with specific decommissioning performance activities, submit decommissioning plans, decommissioning cost estimates, and/or provide proof of financial assurance to state and/or local jurisdictions. The remaining 35 states and the District of Columbia leave solar decommissioning policies completely to local governments. Of those 35 states, 9 states ${ }^{15}$ have model ordinances, templates, or other resources that local governments may - but are not required - to use in developing their local solar decommissioning policies.

Fifteen U.S. states ${ }^{16}$ have enacted various types of statewide solar decommissioning policies that include:

- State-level regulatory frameworks in which mandatory decommissioning requirements are overseen by state regulatory authorities and may require solar project developers to submit a decommissioning plan and proof of financial assurance depending on the project location or operating capacity (Louisiana, Minnesota, Montana, New Hampshire, North Dakota, Vermont).

- Hybrid regulatory frameworks in which mandatory decommissioning requirements are overseen by state and/or local regulatory authorities and may require solar project developers to submit decommissioning plans and/or proof of financial assurance depending on the project location or operating capacity (California, Hawaii, Illinois, New Jersey, Nebraska, Oklahoma, Virginia, and Wyoming).

- Optional state-level decommissioning program, which allow solar developers to submit decommissioning plans and proof of financial assurance to state entities in lieu of obtaining local city and county government permits and approvals (Washington).

For a summary of the 15 state solar decommissioning policies analyzed in this report, see Appendix A.1. In addition, Figure 1 maps the state-level, hybrid, and optional statewide solar decommissioning policies in the United States.

\footnotetext{
${ }^{14}$ Any person may apply to the BLM to obtain a right-of-way (ROW) to develop a solar energy facility on BLM managed land. The BLM is authorized to grant, issue, and renew ROWs upon, under, or through BLM managed public lands for electric energy generation, transmission, and distribution systems pursuant to the Federal Land Policy and Management Act (FLPMA) (43 U.S.C. 1761(a)(4)). The term "ROW" includes easements, leases, permits, or licenses to occupy, use, or traverse public lands (43 U.S.C. 1702(f)). A BLM solar ROW includes solar collector, towers, turbine generators, generators, thermal storage, access, roads, electrical and transmission facilities, transmission lines, and interconnection and support facilities (BLM 2018).

${ }^{15}$ Georgia, Iowa, Massachusetts, New York, North Carolina, Oregon, Rhode Island, Texas, Wisconsin

${ }^{16}$ California, Hawaii, Louisiana, Minnesota, Montana, Nebraska, New Hampshire, New Jersey, North Dakota, Oklahoma, Vermont, Virginia, Washington, and Wyoming
} 


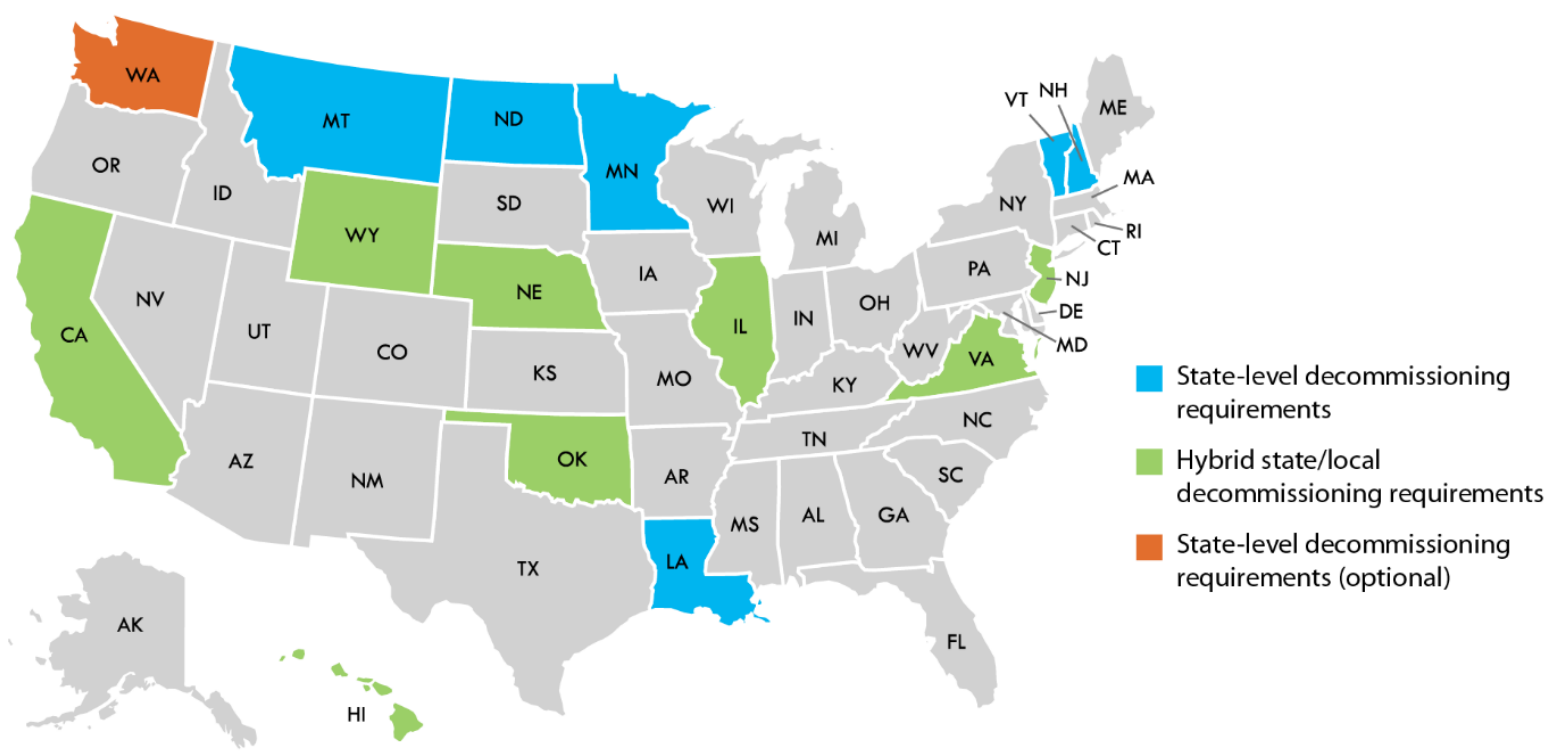

Figure 1. Map of state solar decommissioning policies in the United States

Solar decommissioning policies in the United States often require a project developer draft and submit a decommissioning plan to federal, state and/or local authorities. Solar decommissioning plans typically include the following information:

- The projected lifespan of the solar project

- A site reclamation plan, a restoration plan, or both

- Plans for transportation, salvage, and disposal of the solar project equipment and infrastructure (e.g., modules, inverters, supports, and cables)

- Cost estimates for solar system decommissioning (e.g., costs for removal of solar project equipment and infrastructure, land restoration and reclamation, and insurance requirements)

- Estimates of the salvage value for solar project equipment and infrastructure (e.g., modules, inverters, supports, and cables)

- A description of any expected impacts on natural resources

- Estimated timelines for completion of decommissioning activities (NYSERDA 2020). ${ }^{17}$

Solar decommissioning policies in the United States also often require owners to issue a financial assurance instrument (e.g., bond, guarantee, or escrow fund) to cover the cost of system decommissioning prior to project construction or at some point in time after project operation (Maamari 2018; NYSERDA 2020). ${ }^{18}$ The financial assurance typically must cover the estimated costs of labor, infrastructure removal and transportation, recycling and/or disposal, and site restoration and reclamation for system decommissioning. Table 1 provides an overview types of

\footnotetext{
${ }^{17}$ N.D. Admin. Code $\S \S 69-09-10-01,69-09-10-06$; Mont. Admin. R. 17.86.105; La. Admin. Code tit. 43:V, §§ 953, 955; N.H. Admin. R. Site 301.08(d)(2); Vt. PUC Rule 5.904; Cal. Code Regs. tit. $14 \S 3108$; N.J. Admin Code $\S \S$ 2:76-2A.12N; 7:50-5.36; Wyo. Stat. Ann. § 18-5-503

${ }^{18}$ Mont. Admin. R. 17.86.102, 106, 115; Vt. PUC Rule 5.904; La. Admin. Code tit. 43:V, §§ 953, 955; Minn. R. 7854.0500; N.H. Admin. R. Site 301.08(d)(2).
} 
financial assurance instruments typically used to ensure solar project decommissioning requirements are met.

Table 1. Financial Assurance Instruments

\begin{tabular}{|l|l|l|}
\hline $\begin{array}{l}\text { Instrument } \\
\text { Type }\end{array}$ & Instrument Description & $\begin{array}{l}\text { Instrument Form and/or Funding } \\
\text { Mechanism }\end{array}$ \\
\hline $\begin{array}{l}\text { Surety Bonds } \\
\text { and Letters } \\
\text { of Credit }\end{array}$ & $\begin{array}{l}\text { An agreement in which a third party (e.g., } \\
\text { bank, insurance company) agrees to uphold } \\
\text { the financial obligations of the developer for } \\
\text { the benefit of the landowner and/or state or } \\
\text { local entity with jurisdiction if the developer } \\
\text { defaults or abandons the project. }\end{array}$ & $\begin{array}{l}\text { A surety bond may be paid as a lump } \\
\text { capital sum, as a percentage of the } \\
\text { total cost of the bond, or incrementally } \\
\text { over time. }{ }^{20} \text { State policies may vary in } \\
\text { mandating when bonds must be fully } \\
\text { funded (e.g., prior to project } \\
\text { construction, during operation, prior to } \\
\text { decommissioning). }\end{array}$ \\
\hline $\begin{array}{l}\text { Parent } \\
\text { Guarantees }\end{array}$ & $\begin{array}{l}\text { A contractual promise given by a parent } \\
\text { company for the benefit of the landowner } \\
\text { and/or state or local entity with jurisdiction to } \\
\text { secure the performance of a subsidiary } \\
\text { company's (i.e., the developer) financial and } \\
\text { legal obligations (e.g., financial assurance } \\
\text { and solar project decommissioning } \\
\text { requirements) if the subsidiary company } \\
\text { defaults or abandons the project. }\end{array}$ & $\begin{array}{l}\text { A parent guarantee takes the form of a } \\
\text { negotiated contract and may be } \\
\text { executed as a deed. State policies may } \\
\text { vary in mandating when guarantees } \\
\text { must be executed (e.g., prior to project } \\
\text { construction, during project operation, } \\
\text { prior to decommissioning). }\end{array}$ \\
\hline $\begin{array}{l}\text { Escrow } \\
\text { Accounts }\end{array}$ & $\begin{array}{l}\text { A trust account held by a lender (e.g., bank, } \\
\text { title company) that holds funds necessary to } \\
\text { complete solar project decommissioning until } \\
\text { the end of the project. }\end{array}$ & $\begin{array}{l}\text { A2 } \\
\text { typically escrow accounts must be fully } \\
\text { funded prior to project construction and } \\
\text { remain fully funded for the duration of } \\
\text { project operation. }{ }^{23}\end{array}$ \\
\hline
\end{tabular}

Figure 2 shows jurisdictions that have statewide financial assurance requirements for solar project decommissioning and states that leave financial assurance requirements to local and municipal governments.

${ }^{19}$ Surety Bond. Black's Law Dictionary (11th ed. 2019); Performance Bond. Black's Law Dictionary (11th ed. 2019).

${ }^{20}$ Maamari 2018.

${ }^{21}$ Guarantee. Black's Law Dictionary (11th ed. 2019).

${ }^{22}$ Escrow. Black's Law Dictionary (11th ed. 2019).

${ }^{23}$ Maamari 2018. 


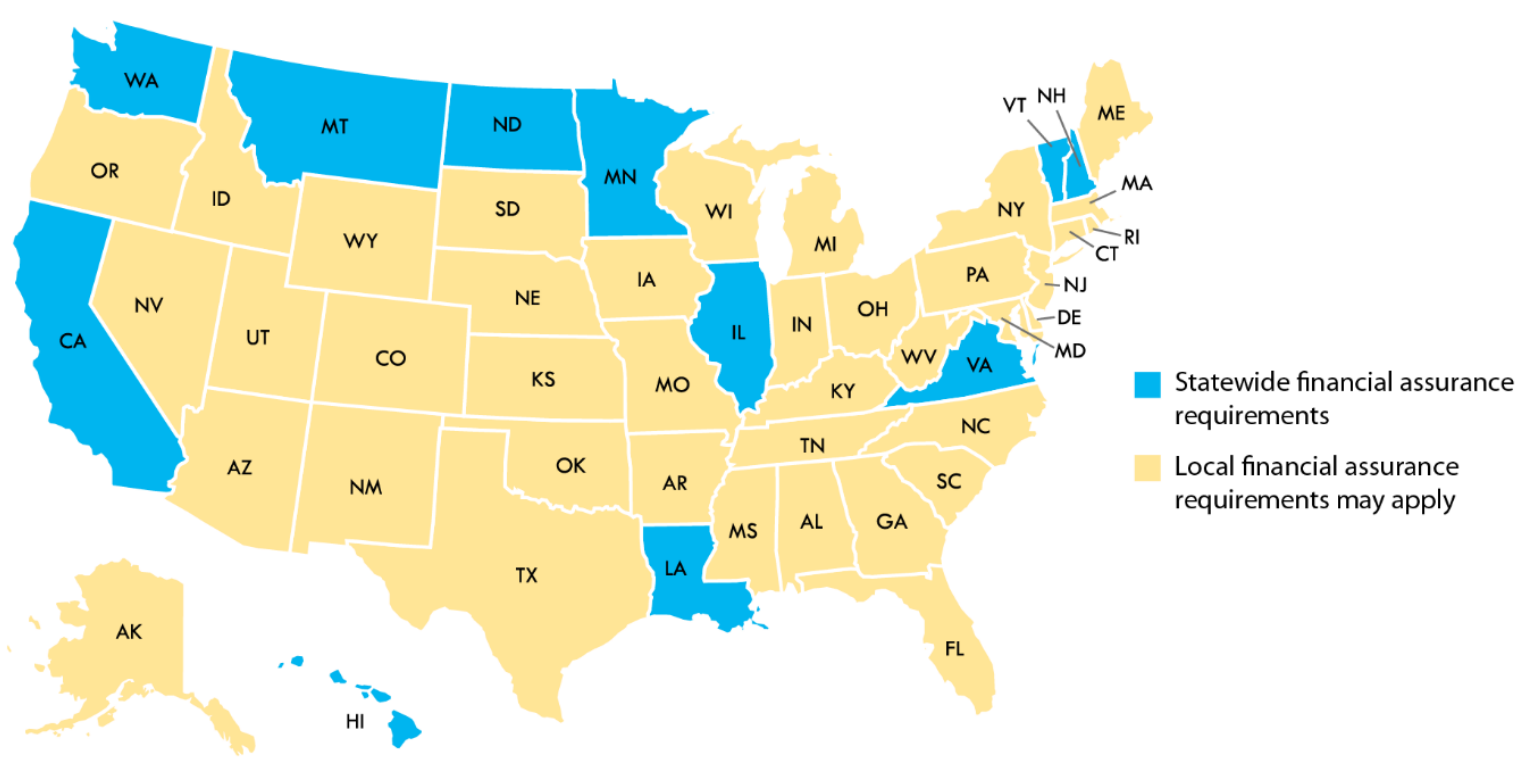

Figure 2. Map of statewide solar decommissioning financial assurance policies in the United States

In addition, solar decommissioning policies in the United States are often tied to an approval required for initial project development (e.g., site license, right-of-way). These policies typically mandate compliance with solar decommissioning requirements like the submission of a plan and/or proof of financial assurance as a pre-requisite or condition of approval needed for project construction or operation.

In this report, we provide a survey and analysis of U.S. federal and state solar decommissioning policies. Section 2 provides an overview of the one U.S. federal land management agency (BLM) with a solar decommissioning policy. Section 3 summarizes mandatory state-level solar decommissioning policies, Section 4 summarizes mandatory hybrid state/local solar decommissioning policies, and Section 5 summarizes the optional solar decommissioning policy enacted in the state of Washington. In Section 6, we discuss some potential impacts of solar decommissioning policies on construction timelines, project development, project operations, and EoL equipment management decisions, and ideas for future study.

Our results are based on legal and literature-based research, as well as a 50-state survey to identify enacted statewide solar decommissioning policies. We also conducted a survey of the four federal land management agencies (BLM, Forest Service, Fish and Wildlife Service, and National Park Service) and determined that BLM is currently the only major federal land management agency with a solar decommissioning policy. Accordingly, our analysis of federal decommissioning policies is limited to BLM. Decommissioning policies developed by other federal agencies, which may have solar installations on property or land under their jurisdiction (e.g., the Department of Defense, the Bureau of Indian Affairs) were not addressed within this report. Local and municipal ordinances addressing solar decommissioning requirements are also outside the scope of this report. In addition, this report does not provide an in-depth analysis or comparison of cost-estimate calculations by jurisdiction or the impacts solar decommissioning requirements, such as financial assurance instruments, have on solar project development, project operations, EoL equipment management decisions, or system repowering evaluations. 


\section{Bureau of Land Management Solar Decommissioning Policy}

The Bureau of Land Management (BLM) is the only federal land management agency (that the authors found) that has a decommissioning policy for solar projects located on public lands. ${ }^{24} \mathrm{~A}$ developer must submit a decommissioning plan and proof of financial assurance to BLM prior to approval for a solar right-of-way (ROW) to use BLM land (BLM 2017).

The BLM approved its first solar project in October 2010, and as of May 2021, has permitted 37 utility-scale projects totaling more than 7,000 $\mathrm{MW}_{\mathrm{dc}}$ (BLM nd). BLM-approved solar projects are predominately PV projects but also include concentrated solar power projects. Of the 37 BLMpermitted solar projects, 2 have been decommissioned, 22 are in operation, and 13 are pending construction (BLM 2021). Table 2 analyzes the size and land acreage of BLM-approved solar projects. The 37 solar projects analyzed have a median capacity size of $175 \mathrm{MW}$ utilizing 1,077 acres of BLM land.

Table 2. Solar Projects with a BLM Solar Right-of-Way

\begin{tabular}{|c|c|c|c|c|}
\hline & Range & Mean & Median & Mode \\
\hline $\begin{array}{c}\text { Potential } \\
\text { Capacity Size } \\
\left.\mathbf{( M W}_{\text {dc }}\right)^{25}\end{array}$ & $0.05 \mathrm{MW}-690 \mathrm{MW}$ & $212.57 \mathrm{MW}$ & $175 \mathrm{MW}$ & $250 \mathrm{MW}$ \\
\hline $\begin{array}{c}\text { BLM Land } \\
\text { Acreage }^{\mathbf{2 6}}\end{array}$ & $\begin{array}{c}0.13 \text { acres }-7,063 \\
\text { acres }\end{array}$ & $1,506.89$ acres & 1,077 acres & 1,661 acres \\
\hline
\end{tabular}

\section{Decommissioning Requirements}

A solar facility owner must submit a decommissioning plan to BLM prior to project construction as a prerequisite to approval for a solar ROW. The decommissioning plan must include a description of the reclamation and restoration activities as well as a reclamation cost estimate (RCE) (BLM 2017). ${ }^{27}$ The RCE must take into account environmental liabilities such as "those from the use of hazardous materials waste, costs of decommissioning, disposal of the facility and equipment, and land restoration (e.g., revegetation, recontouring, and soil stabilization)" (BLM

\footnotetext{
${ }^{24}$ There are four federal land management agencies that manage $95 \%$ of all public lands (approximately 606 million acres) in the United States including the BLM, the Forest Service (FS), U.S. Fish and Wildlife Service (FWS), and National Park Service (NPS) (CRS 2021). ${ }^{24}$ The BLM manages 244 million acres, the FS manages 193 million acres, the FWS manages 89 million acres, and the NPS manages 80 million acres (CRS 2021). The BLM has determined that more than 19 million acres of the land it administers in California, Nevada, Arizona, New Mexico, Colorado, and Utah has excellent solar energy development potential (BLM 2021). However, the FS, FWS, and NPS do not appear to have formal guidance, directives, or regulations addressing utility-scale solar energy project decommissioning requirements. Accordingly, the scope of federal decommissioning policies analyzed in this report is limited to the BLM.

${ }^{25}$ This calculation includes the 2 projects that were approved and have since been decommissioned, and excludes 2 maintenance facility projects, which have no potential generating capacity.

${ }^{26}$ This calculation includes all 37 BLM-approved solar projects.

${ }^{27} 43$ C.F.R. § $2805.20(\mathrm{a})(3),(5)$
} 
2017). ${ }^{28}$ However, the RCE may not include the estimated salvage value for structures, equipment, or materials (i.e., cost offsets) (BLM 2015).

\section{Financial Assurance}

A solar facility owner must also provide proof of financial assurance through a bond, which is due prior to project construction as part of the decommissioning plan (BLM 2017). ${ }^{29}$ The amount of financial assurance must be based on the RCE, which is currently set to at least $\$ 10,000 /$ acre. ${ }^{30,} 31$ The BLM adjusts the RCE bond requirement for inflation every 10 years (BLM 2017). ${ }^{32}$

Historically, utility-scale solar projects on BLM land are large developments with an average operating capacity of more than $200 \mathrm{MW}$ dc utilizing more than 1,500 acres of land (BLM 2021) (see Table 2 above). At $\$ 10,000$ /acre a 1,500-acre project would require a $\$ 15,000,000$ decommissioning assurance bond (EIA 2019; SEIA 2021; BLM 2020). ${ }^{33}$ Anecdotal evidence indicates that BLM's financial assurance requirement for solar project decommissioning (a capital cost due prior to project construction) is a financial barrier for large, utility-scale solar projects which has led to project delays and project cancellations. ${ }^{34}$

In 2020, the Department of Interior approved the Gemini Solar Project for development on BLM managed land - the largest solar project in U.S history (BLM 2020). The 690 MW proposed solar project will be located on approximately 7,100 acres of BLM land in Nevada and required at least a $\$ 71,000,000$ decommissioning bond prior to project development pursuant to BLM regulations (BLM 2020).

Table 3 provides a list of BLM permitted solar projects that are pending construction - one of which has been pending construction for approximately 8.5 years (BLM 2021). ${ }^{35}$ For a full list of all BLM solar projects, see Appendix A.2.

2843 C.F.R. $\S 2805.20(\mathrm{a})(3),(5)$

2943 C.F.R. $\S 2805.20(\mathrm{~b})$

${ }^{30}$ In 2016, the BLM published final rules establishing minimum bonding amounts for solar project decommissioning (\$10,000/acre) and wind project decommissioning (\$10,000/turbine) (43 C.F.R. $\S \S 2800,2880)$. Notably, a 2012 Office of the Inspector General (OIG) Report stated that "BLM field personnel did not know how the $\$ 10,000$ minimum bond amount was developed" (OIG 2012). The OIG report also noted that at the time the report was published in 2012, the BLM was still in the process of developing a method to determine a minimum bonding amount for solar projects (OIG 2012).

3143 C.F.R. $\S 2805.20(a)(3)$, (b)

3243 C.F.R. $\S 2805.20$ (b)

${ }_{33}$ Megan Day, National Renewable Energy Laboratory, personal communication, 2021.

${ }^{34}$ Megan Day, National Renewable Energy Laboratory, email, October 19, 2020.

35 The authors do not have insight as to the reason these projects are pending construction, nor does this report speculate on a particular reason for project construction delay. 
Table 3. Pending Construction - Solar Projects with a BLM Solar Right-of-Way

\begin{tabular}{|c|c|c|c|c|}
\hline Project Name & $\begin{array}{c}\text { Potential MW } \\
\text { Capacity }\end{array}$ & BLM Acreage & $\begin{array}{c}\text { Right-of-Way } \\
\text { Issuance Date }\end{array}$ & $\begin{array}{c}\text { Time from Right- } \\
\text { of-Way } \\
\text { Issuance }\end{array}$ \\
\hline $\begin{array}{c}\text { Sonoran Solar } \\
\text { Energy Solar } \\
\text { Project }\end{array}$ & $300 \mathrm{MW}$ & $2,335.60$ acres & October 2012 & 8 years, 7 months \\
\hline Desert Harvest & $150 \mathrm{MW}$ & 1,412 acres & September 2013 & 7 years, 8 months \\
\hline McCoy Solar Unit & $500 \mathrm{MW}$ & 2,180 acres & August 2014 & 6 years, 9 months \\
\hline $\begin{array}{c}\text { Moapa Sola } \\
\text { Energy Center }\end{array}$ & $200 \mathrm{MW}$ & 119 acres & August 2015 & 5 years, 9 months \\
\hline Harry Allen & $130 \mathrm{MW}$ & 640 acres & April 2018 & 3 years, 1 month \\
\hline Palen & $500 \mathrm{MW}$ & 3,140 acres & March 2019 & 2 years, 2 months \\
\hline Dodge Flat & $200 \mathrm{MW}$ & 3,500 acres & November 2019 & 1 year, 6 months \\
\hline $\begin{array}{c}\text { Dry Lake Solar } \\
\text { Energy Center }\end{array}$ & $130 \mathrm{MW}$ & 660 acres & December 2019 & 1 year, 5 months \\
\hline $\begin{array}{c}\text { Eagle Shadow } \\
\text { Mountain }\end{array}$ & $420 \mathrm{MW}$ & 144 acres & April 2020 & 1 year, 1 month \\
\hline $\begin{array}{c}\text { Yellow Pine } \\
\text { Crimson Solar }\end{array}$ & $500 \mathrm{MW}$ & 2,987 acres & January 2021 & 4 months \\
\hline
\end{tabular}

36 This data was collected in May 2021, therefore the time from right-of-way issuance was calculated up to May 2021. 


\section{States with Mandatory State-Level Solar Decommissioning Policies}

This section analyzes 6 state-level solar decommissioning policies in the United States that require a project developer to submit a decommissioning plan and financial assurance to a state entity that has the authority to review, approve, and enforce the requirements. Notably, these state-level decommissioning policies are often inclusive of other technologies (e.g., oil and gas refineries, wind, geothermal, and hydropower technologies) and may not be narrowly tailored to solar or renewable energy facilities. Six states (Louisiana, Minnesota, Montana, New Hampshire, North Dakota, and Vermont) have enacted state-level policies that require project developers to submit decommissioning plans and proof of financial assurance to the state regulatory authority depending on the proposed project operating capacity or facility location. In 5 of those states (Louisiana, Minnesota, New Hampshire, North Dakota, and Vermont) compliance with decommissioning requirements is a condition of approval for a permit/license necessary for site access, project construction, or project operation. Louisiana, Montana, North Dakota, and Vermont also require solar facility owners to provide periodic updates to decommissioning plans, cost estimates, and/or financial assurance instruments after project construction or operation. Table 4 describes the threshold for state-level solar decommissioning policies and provides a summary of the requirements.

Table 4. Regulatory Threshold for State-Level Solar Decommissioning Policies and Summary of Requirements

\begin{tabular}{|l|l|}
\hline State & Regulatory Threshold and Summary of Requirements \\
\hline Louisiana & $\begin{array}{l}\text { In Louisiana, as a condition of approval for an Alternative Energy Source Lease } \\
\text { (AESL), the owner of an alternative energy source facility }{ }^{37} \text { located on state land } \\
\text { must submit a decommissioning plan and financial assurance to the Louisiana } \\
\text { Department of Natural Resources prior to commencing decommissioning activities. } \\
\text { Within } 60 \text { days of completing decommissioning activities, the facility owner must } \\
\text { notify the department and submit a decommissioning report that includes a } \\
\text { summary of decommissioning activities and a description of any mitigation } \\
\text { measures used during decommissioning. }{ }^{38}\end{array}$ \\
\hline Minnesota & $\begin{array}{l}\text { In Minnesota, as a condition of a Site License, the owner of a large electric power } \\
\text { generating plant }{ }^{39} \text { with a capacity of } 50 \text { MW or greater must submit a } \\
\text { decommissioning plan and financial assurance to the Minnesota Public Utilities } \\
\text { Commission (PUC). } .^{40,41}\end{array}$ \\
\hline
\end{tabular}

${ }^{37}$ In Louisiana, an "alternative energy source" includes wind energy, geothermal energy, geothermal energy, solar energy, and hydrokinetic energy (La. Admin. Code tit. 43:V, § 909). Although the Louisiana decommissioning regulations refer to "alternative energy source facilities," that term is not defined within the regulations.

${ }^{38}$ La. Admin. Code tit. 43:V, $\S \S 921,961,967$

${ }^{39}$ In Minnesota, "large electric power generating plants" means electric power generating equipment and associated facilities designed for or capable of operation at a capacity of $50 \mathrm{MW}$ or greater (Minn. Stat. § 216E.01).

${ }^{40}$ Minn. Stat. $\S \S 216$ E.01, 216E.02; Minn. R. 7854.0500

${ }^{41}$ By statute, the Minnesota PUC has authority to issue Site Licenses for large solar facilities with a capacity of 50 MW or greater (Minn. Stat. $\S \S 216 E .01,216$ E.02). However, the Minnesota PUC has not drafted administrative rules addressing site licenses specific to solar facilities. Rather, in applications for Site Licenses for large solar facilities, the Minnesota PUC cites to administrative rules related to site permit requirements for large wind facilities (PUC Docket No. E-6928/GS-14-515). 


\begin{tabular}{|c|c|}
\hline State & Regulatory Threshold and Summary of Requirements \\
\hline Montana & $\begin{array}{l}\text { In Montana, the owner of a facility }{ }^{42} \text { with a capacity of } 2 \mathrm{MW} \text { or greater must } \\
\text { submit (1) a decommissioning plan within } 12 \text { months prior to operation of the } \\
\text { facility and (2) financial assurance at any time prior to } 15^{\text {th }} \text { year of the facility's } \\
\text { operation to the Montana Department of Environmental Quality. Decommissioning } \\
\text { plans must be updated every } 5 \text { years after the facility is bonded. }{ }^{43}\end{array}$ \\
\hline New Hampshire & $\begin{array}{l}\text { In New Hampshire, as a condition of approval for a Certificate of Site and Facility } \\
\text { Application, the owner of an energy facility }{ }^{44} \text { larger than } 30 \mathrm{MW} \text { must submit a } \\
\text { decommissioning plan and proof of financial assurance to the New Hampshire Site } \\
\text { Evaluation Committee prior to construction of the facility. }{ }^{45}\end{array}$ \\
\hline North Dakota & $\begin{array}{l}\text { In North Dakota, as a condition of approval for a Certificate of Operation, the } \\
\text { owner of a facility }{ }^{46} \text { with a capacity of } 500 \text { kilowatts }(\mathrm{kW}) \text { or greater must submit a } \\
\text { decommissioning plan and proof of financial assurance to the North Dakota Public } \\
\text { Service Commission (PSC) prior to the operation of the facility. The facility owner } \\
\text { must file an updated decommissioning cost estimate with the PSC } 10 \text { years after } \\
\text { the decommissioning cost estimate is initially approved and then every } 5 \text { years } \\
\text { after until decommissioning is complete. }{ }^{47}\end{array}$ \\
\hline Vermont & $\begin{array}{l}\text { In Vermont, as a condition of approval for a Certificate of Public Good the owner of } \\
\text { a facility }{ }^{48} \text { with a capacity of greater than } 500 \mathrm{~kW} \text { must submit a decommissioning } \\
\text { plan and financial assurance to the Vermont Public Utility Commission (PUC) prior } \\
\text { to construction. Facility owners must adjust the financial assurance instrument } \\
\text { every } 3 \text { years to account for inflation and then file a report with the PUC and the } \\
\text { Vermont Department of Public Service describing any adjustments. }{ }^{49}\end{array}$ \\
\hline
\end{tabular}

${ }^{42}$ In Montana, "facility" means a wind generation facility or a solar facility (Mont. Admin. R. 17.86.101).

${ }_{43}^{43}$ Mont. Admin. R. 17.86.102, 17.86.105

${ }^{44}$ In New Hampshire, an "energy facility" includes oil refineries, gas plants, electric generating stations, electric transmissions lines, and renewable energy facilities (N.H. Rev. Stat. Ann. § 162-H:2 (VII)). A "renewable energy facility" is defined as electric generating station equipment and associated facilities with a capacity of greater than 30 megawatts and powered by wind energy, geothermal energy, hydrogen, ocean energy, methane gas, biomass technologies, solar technologies, or hydroelectric energy (N.H. Rev. Stat. Ann. § 162-H:2 (XII)).

${ }^{45}$ N.H. Rev. Stat. Ann. § 162-H:2, 7

${ }^{46}$ In North Dakota, a "facility" means a commercial solar energy conversion facility, including solar modules, racking, anchors, bolts, foundations, bases, transformers, cables, lines, substations, concrete fences, facility access roads, towers, and all areas disturbed by the construction, operation, maintenance, or decommissioning activities (N.D. Admin. Code § 69-09-10-01).

${ }^{47}$ N.D. Admin. Code $\S 69-09-10-01,06$

${ }^{48}$ In Vermont, "facility" means an electric generation, transmission, or natural gas facility (Vt. PUC Rule 5.904).

4930 V.S.A. § 248; Vt. PUC Rule 5.904 


\subsection{State-Level Solar Decommissioning Plan Requirements}

State-level solar decommissioning policies vary by jurisdiction but often require the submission of a decommissioning plan that incorporates site reclamation and restoration details, as well as a cost estimate. Six states (Louisiana, Minnesota, Montana, New Hampshire, North Dakota, and Vermont) require solar developers to submit decommissioning plans to a state regulatory entity. Five of those six states (Minnesota, Montana, New Hampshire, North Dakota, and Vermont) require a decommissioning cost estimate as part of the plan submission. Three states (Montana, ${ }^{50}$ New Hampshire, ${ }^{51}$ and North Dakota) ${ }^{52}$ require decommissioning plans, and/or the cost estimate be prepared by a qualified third party at the facility owner's expense. Table 5 summarizes statelevel decommissioning plan requirements for Louisiana, Minnesota, Montana, New Hampshire, North Dakota, and Vermont.

Table 5. State-level Solar Decommissioning Plan Requirements

\begin{tabular}{|c|c|}
\hline State & Requirements \\
\hline Louisiana & $\begin{array}{l}\text { Decommissioning plans must include: } \\
\text { - A proposed decommissioning schedule } \\
\text { - A description of facilities that will be removed or kept in place } \\
\text { - A description of removal methods and site clearance activities } \\
\text { - Transportation, disposal, or salvage plans } \\
\text { - A description of resources, conditions, or activities potentially affected by } \\
\text { - decommissioning } \\
\text { - Results of recent biological surveys conducted in the site area } \\
\text { features during decommissioning. }{ }^{53}\end{array}$ \\
\hline Minnesota & $\begin{array}{l}\text { Decommissioning plans must include information about the anticipated manner in } \\
\text { which the project will be decommissioned, and the site restored. The } \\
\text { decommissioning plan must also include a detailed cost estimate. }{ }^{54}\end{array}$ \\
\hline Montana & $\begin{array}{l}\text { Decommissioning plans must include: } \\
\text { - A proposed decommissioning schedule } \\
\text { - Information about site restoration and reclamation to preconstruction topography } \\
\text { - Information about dismantling, removal, and regrading of all aboveground and } \\
\text { underground infrastructure, including access roads } \\
\text { - Information about repair and reconstruction of public roads, culverts, and natural } \\
\text { drainage damaged by decommissioning activities } \\
\text { - A detailed cost estimate }\end{array}$ \\
\hline
\end{tabular}

${ }^{50}$ In Montana, a detailed estimate of the salvageable value of the facility must be prepared by an independent evaluator and included as part of the decommissioning plan (Mont. Admin. R. 17.86.105).

${ }^{51}$ In New Hampshire, decommissioning plans must be prepared by a qualified, independent individual who has demonstrated knowledge and experience in solar energy facility projects and cost estimates (N.H. Rev. Stat. Ann. $\S$ 162-H:2, 7).

${ }^{52}$ In North Dakota, decommissioning plans must be prepared by a professional licensed engineer (N.D. Admin. Code $\S \S 69-09-10-01,69-09-10-06)$.

${ }^{53}$ La. Admin. Code tit. 43:V, § 965

${ }^{54}$ Minn. R. 7854.0500 


\begin{tabular}{|c|c|}
\hline State & Requirements \\
\hline & - A detailed estimate of the salvageable value of the facility. ${ }^{55}$ \\
\hline New Hampshire & $\begin{array}{l}\text { Decommissioning plans must include information about removal of all underground } \\
\text { infrastructure less than four feet below ground surface and must also include a } \\
\text { detailed cost estimate. }{ }^{56} \text { Decommissioning plans must be prepared by a qualified, } \\
\text { third-party. }{ }^{57}\end{array}$ \\
\hline North Dakota & $\begin{array}{l}\text { Decommissioning plans must address: } \\
\text { - Site restoration and reclamation to preconstruction topography } \\
\text { - Dismantling and removal of all aboveground infrastructure (e.g., modules, } \\
\text { supports, and inverters) and underground infrastructure (e.g., foundations, } \\
\text { cables, and equipment) } \\
\text { - Expected effects of decommissioning on natural resources }{ }^{58} \\
\text { - A detailed decommissioning cost estimate } \\
\text { Decommissioning plans must be prepared by a qualified, third-party. }{ }^{59}\end{array}$ \\
\hline Vermont & $\begin{array}{l}\text { Decommissioning plans must address: } \\
\text { - Labor, equipment, transportation, and disposal costs associated with facility } \\
\text { removal (e.g., infrastructure including modules, supports, and inverters) } \\
\text { - Site restoration and reclamation to preconstruction condition, including removal } \\
\text { of non-native soils, fences, and access roads } \\
\text { - A detailed decommissioning cost estimate. }{ }^{60}\end{array}$ \\
\hline
\end{tabular}

As noted above, Minnesota, Montana, New Hampshire, North Dakota, and Vermont mandate that decommissioning plans include a cost estimate for decommissioning the solar facility. The state specifications regarding costs estimate calculation methods and what must be included or excluded within the cost estimate vary by jurisdiction. Louisiana does not mandate that decommissioning plans include a cost estimate. Table 6 summarizes cost estimate requirements.

Table 6. State-level Solar Decommissioning Cost Requirements

\begin{tabular}{|l|l|l|}
\hline State & Cost Requirements & Calculation Method \\
\hline Louisiana & N/A & N/A \\
\hline Minnesota & $\begin{array}{l}\text { No requirements are articulated within the } \\
\text { regulations other than that the owner must } \\
\text { provide a cost estimate. }\end{array}$ & Not specified \\
\hline
\end{tabular}

${ }^{55}$ Mont. Admin. R. 17.86.105

${ }^{56}$ N.H. Admin. R. Site 301.08(d)(2))

${ }^{57}$ N.H. Rev. Stat. Ann. § 162-H:2, 7

${ }^{58}$ N.D. Admin. Code $\S \S 69-09-10-01,69-09-10-06$

${ }^{59}$ N.D. Admin. Code $\S \S 69-09-10-01,69-09-10-06$

${ }^{60}$ Vt. PUC Rule 5.90

4

${ }^{61}$ Minn. R. 7854.0500 


\begin{tabular}{|c|c|c|}
\hline State & Cost Requirements & Calculation Method \\
\hline Montana & $\begin{array}{l}\text { A cost estimate must include: } \\
\text { - A detailed estimate of the anticipated } \\
\text { salvage value of the facility (e.g., } \\
\text { infrastructure including modules, supports, } \\
\text { and inverters) prepared by an independent } \\
\text { evaluator } \\
\text { - Any other expenses related to } \\
\text { decommissioning, which are the } \\
\text { responsibility of the solar facility owner. }{ }^{62}\end{array}$ & $\begin{array}{l}\text { Current machinery production } \\
\text { handbooks, publications, or other } \\
\text { substantiated methods approved by } \\
\text { the Montana Department of } \\
\text { Environmental Quality } 63\end{array}$ \\
\hline $\begin{array}{l}\text { New } \\
\text { Hampshire }\end{array}$ & $\begin{array}{l}\text { Cost estimates must exclude the anticipated } \\
\text { salvage value (i.e., potential cost offsets) of } \\
\text { the facility. } 64\end{array}$ & Not specified \\
\hline North Dakota & $\begin{array}{l}\text { Cost estimates must exclude the anticipated } \\
\text { salvage value (i.e., potential cost offsets) of } \\
\text { the facility. It must be updated } 10 \text { years after } \\
\text { initial approval and every } 5 \text { years after that } \\
\text { until decommissioning is complete }{ }^{65}\end{array}$ & $\begin{array}{l}\text { Not specified; however, a facility } \\
\text { owner must include a description of } \\
\text { the cost estimate calculation method } \\
\text { used }\end{array}$ \\
\hline Vermont & $\begin{array}{l}\text { A cost estimate must include: } \\
\text { - Labor, equipment, transportation, and } \\
\text { disposal costs associated with facility } \\
\text { removal (e.g., infrastructure including } \\
\text { modules, supports, inverters) } \\
\text { - Costs of site reclamation to } \\
\text { preconstruction condition } \\
\text { - Costs of applicable federal, state, and } \\
\text { local permits } \\
\text { - Costs associated with decommissioning } \\
\text { activity management, supervision, and } \\
\text { safety } \\
\text { A cost estimate must exclude the anticipated } \\
\text { salvage value (i.e., potential cost offsets) of } \\
\text { the facility }\end{array}$ & Not specified \\
\hline
\end{tabular}

${ }^{62}$ Mont. Admin. R. 17.86.105

${ }^{63}$ Mont. Admin. R. 17.86.105

${ }^{64}$ N.H. Admin. R. Site 301.08(d)(2)).

${ }^{65}$ N.D. Admin. Code $\S \S 69-09-10-01,69-09-10-06$

${ }^{66}$ N.D. Admin. Code $\S \S 69-09-10-01,69-09-10-06$

${ }^{67}$ Vt. PUC Rule 5.904

${ }^{68}$ Vt. PUC Rule 5.904 


\subsection{State-level Solar Decommissioning Financial Assurance Requirements}

State-level solar decommissioning policies vary by jurisdiction but often require financial assurance to guarantee funds will be available for system decommissioning activities and site restoration. These policies may mandate a preferred financial assurance instrument (e.g., surety or performance bond), an issuance date for when the financial assurance is due (e.g., prior to facility construction, at a specified point during facility operation, along with the decommissioning plan), and a specific calculation method (e.g., using a cost estimate, liability insurance, or salvage value of the facility infrastructure). Six states (Louisiana, Minnesota, Montana, New Hampshire, North Dakota, and Vermont) require solar facility owners to submit financial assurance to a state entity to ensure funds will be available for decommissioning and site restoration. Four of those six states (Louisiana, Minnesota, New Hampshire, and Vermont) all require submittal of financial assurance prior to project construction (i.e., financial assurance is a capital cost). North Dakota requires that a project developer submit two installments of financial assurance, the first installment must be submitted prior to project construction, and the second after construction is complete but before project operation (i.e., financial assurance is a capital cost). Montana allows project developers to submit financial assurance at any time prior to the fifteenth year of project operation (i.e., financial assurance is an operating cost). Table 7 summarizes these financial assurance requirements.

Table 7. State-level Solar Decommissioning Financial Assurance Requirements

\begin{tabular}{|c|c|c|c|c|}
\hline State & $\begin{array}{l}\text { Financial } \\
\text { Assurance } \\
\text { Required }\end{array}$ & Issuance Dates & $\begin{array}{l}\text { Instrument } \\
\text { Type }\end{array}$ & $\begin{array}{l}\text { Calculation Methods, Contents, } \\
\text { and Amounts }\end{array}$ \\
\hline Louisiana $^{69}$ & Yes & $\begin{array}{l}\text { Prior to receiving } \\
\text { an AESL (see } \\
\text { Table 1) }\end{array}$ & Bond & $\begin{array}{l}\text { The Louisiana Department of } \\
\text { Natural Resources determines } \\
\text { the amount, which can be no less } \\
\text { than } \$ 500,000 \text {, and it may base } \\
\text { the amount on: } \\
\text { - Estimated costs of } \\
\text { decommissioning } \\
\text { - Past due rent and payments } \\
\text { incurred by the owner } \\
\text { - Any other monetary } \\
\text { obligations, including } \\
\text { insurance }{ }^{70} \text { that the owner is } \\
\text { required to maintain for the } \\
\text { duration of the AESL }\end{array}$ \\
\hline Minnesota ${ }^{71}$ & Yes & $\begin{array}{l}\text { Prior to issuance } \\
\text { of the site license }\end{array}$ & Not specified & Not specified \\
\hline
\end{tabular}

${ }^{69}$ La. Admin. Code tit. 43:V, $§ \S 953,955$

${ }^{70}$ The energy facility owner is required to purchase and maintain insurance for the duration of the AESL including workers' compensation insurance with a minimum limit of $\$ 500,000$ per/accident and Commercial General Liability Insurance with a minimum limit of $\$ 1,000,000$ (La. Admin. Code tit. 43:V $\S 953$ ).

${ }^{71}$ Minn. R. 7854.0500 


\begin{tabular}{|c|c|c|c|c|}
\hline State & $\begin{array}{l}\text { Financial } \\
\text { Assurance } \\
\text { Required }\end{array}$ & Issuance Dates & $\begin{array}{l}\text { Instrument } \\
\text { Type }\end{array}$ & $\begin{array}{l}\text { Calculation Methods, Contents, } \\
\text { and Amounts }\end{array}$ \\
\hline & & $\begin{array}{l}\text { and project } \\
\text { construction }\end{array}$ & & \\
\hline Montana $^{72}$ & Yes & $\begin{array}{l}\text { Any time prior to } \\
\text { the } 15^{\text {th }} \text { year of } \\
\text { operation }\end{array}$ & $\begin{array}{l}\text { Surety bond } \\
\text { Collateral bond }\end{array}$ & $\begin{array}{l}\text { The Montana Department of } \\
\text { Environmental Quality (DEQ) } \\
\text { determines the amount, and it } \\
\text { may base the amount on: } \\
\text { - The cost estimate submitted } \\
\text { by the owner (see Table 2) } \\
\text { - Character and nature of } \\
\text { the site } \\
\text { - Costs of managing, } \\
\text { maintaining, and/or } \\
\text { decommissioning the facility } \\
\text { in the event of owner } \\
\text { abandonment } \\
\text { - Current salvage value of the } \\
\text { facility infrastructure (e.g., } \\
\text { modules, supports, inverters, } \\
\text { and other ancillary } \\
\text { equipment). } \\
\text { Reviewed by the DEQ every } \\
5 \text { years. }\end{array}$ \\
\hline $\begin{array}{l}\text { New } \\
\text { Hampshire }{ }^{73}\end{array}$ & Yes & $\begin{array}{l}\text { Prior to issuance } \\
\text { of the site license } \\
\text { and project } \\
\text { construction }\end{array}$ & $\begin{array}{l}\text { - Letter of } \\
\text { credit } \\
\text { - Performance } \\
\text { bond } \\
\text { - Surety bond } \\
\text { - Guarantee }\end{array}$ & Not specified \\
\hline $\begin{array}{l}\text { North } \\
\text { Dakota }^{74}\end{array}$ & Yes & $\begin{array}{l}\text { Owner must issue } \\
\text { the first installment } \\
\text { prior to } \\
\text { construction. } \\
\text { Owner must issue } \\
\text { the second } \\
\text { installment after } \\
\text { construction is } \\
\text { complete but prior } \\
\text { to facility } \\
\text { operation. When } \\
\text { the second } \\
\text { installment is } \\
\text { received, the first }\end{array}$ & $\begin{array}{l}\text { - Letter of } \\
\text { credit } \\
\text { - Performance } \\
\text { bond } \\
\text { - Surety bond } \\
\text { - Guarantee } \\
\text { - Cash } \\
\text { escrow } \\
\text { - Incremental } \\
\text { bond } \\
\text { schedule }\end{array}$ & $\begin{array}{l}\text { The first installment must be in an } \\
\text { amount equal to } 5 \% \text { of the } \\
\text { estimated costs of construction. } \\
\text { The second installment must be } \\
\text { sufficient to cover the costs of } \\
\text { decommissioning. }\end{array}$ \\
\hline
\end{tabular}

${ }^{72}$ Mont. Admin. R. 17.86.102, 106, 115

${ }^{73}$ N.H. Admin. R. Site 301.08(d)(2)

${ }^{74}$ N.D. Admin. Code $§ 69-09-10-08$ 


\begin{tabular}{|c|c|c|c|c|}
\hline State & $\begin{array}{l}\text { Financial } \\
\text { Assurance } \\
\text { Required }\end{array}$ & Issuance Dates & $\begin{array}{l}\text { Instrument } \\
\text { Type }\end{array}$ & $\begin{array}{l}\text { Calculation Methods, Contents, } \\
\text { and Amounts }\end{array}$ \\
\hline & & $\begin{array}{l}\text { installment is } \\
\text { returned. }\end{array}$ & & \\
\hline Vermont $^{75}$ & Yes & $\begin{array}{l}\text { Prior to issuance } \\
\text { of the Certificate } \\
\text { for Public Good } \\
\text { and project } \\
\text { construction }\end{array}$ & Letter of credit & $\begin{array}{l}\text { Must cover the costs of } \\
\text { decommissioning and site } \\
\text { restoration as set forth in the cost } \\
\text { estimate submitted by the owner } \\
\text { (see Table } 2 \text { ) } \\
\text { Must be adjusted every } 3 \text { years } \\
\text { to account for inflation }\end{array}$ \\
\hline
\end{tabular}

\subsection{State-level Solar Decommissioning Policies Oversight Authority and Penalties}

State-level solar decommissioning policies often delegate oversight authority to state entities that stipulate penalties for noncompliance (e.g., enforcement actions, civil or criminal monetary penalties). Six states (Louisiana, Minnesota, Montana, New Hampshire, North Dakota, and Vermont) delegate oversight authority of decommissioning policies to state entities that may assess penalties for noncompliance. State authorities in Louisiana, Minnesota, Montana, New Hampshire, and Vermont may assess civil penalties ranging from $\$ 100$ to $\$ 10,000$ per day for noncompliance with state decommissioning policies. In Louisiana and North Dakota, noncompliance with state decommissioning policies may result in forfeiture of financial assurance. In New Hampshire, noncompliance with state decommissioning policies may result in revocation or suspension of the Certificate of Site and Facility approval required for project operation. Table 8 summarizes state solar decommissioning policy oversight authority and penalties.

Table 8. State-level Solar Decommissioning Policies Oversight Authority and Penalties

\begin{tabular}{|l|l|}
\hline State Authority & Penalties for Noncompliance \\
\hline Louisiana Department of Natural Resources & $\begin{array}{l}\text { - Forfeiture of financial assurance } \\
\text { - Owner liability for facility removal and costs } \\
\text { Minnesota PUC }\end{array}$ \\
\hline Montana Department of Environmental Quality & - Civil action to compel performance \\
\hline & - Civil penalty of up to $\$ 10,000 /$ day $^{77}$ \\
\hline
\end{tabular}

75 Vt. PUC Rule 5.904

${ }^{76}$ La. Admin. Code tit. 43:V, § 969

${ }^{77}$ Minn. Stat. $\S \S 216$ E.17

${ }^{78}$ Mont. Admin. R. 17.86.110; 75-26-304 


\begin{tabular}{|l|l|}
\hline State Authority & Penalties for Noncompliance \\
\hline New Hampshire Site Evaluation Committee & $\begin{array}{l}\text { - Revocation or suspension of Certificate of Site } \\
\text { and Facility Application } \\
\text { - Civil penalty of up to } \$ 10,000 / \text { day or criminal } \\
\text { charges }^{79}\end{array}$ \\
\hline North Dakota Public Service Commission & - Forfeiture of financial assurance ${ }^{80}$ \\
\hline Vermont PUC & $\begin{array}{l}\text { - Civil penalty of up to } \$ 100 \\
\text { - Imprisonment up to } 60 \text { days }^{81}\end{array}$ \\
\hline
\end{tabular}

${ }^{79}$ N.H. Rev. Stat. Ann. $\S \S 162-\mathrm{H}: 12,162-\mathrm{H}-19$

${ }^{80}$ N.D. Admin. Code $\S 69-09-10-09$

8130 V.S.A. $§ 247$ 


\section{States with Hybrid State/Local Solar Decommissioning Policies}

This section analyzes eight hybrid state/local solar decommissioning policies in the United States that require project developers comply with specific performance requirements and/or submit decommissioning plans and financial assurance to state and local entities that have authority to review, approve, and enforce the requirements. Typically, in jurisdictions with hybrid state/local decommissioning policies, the state mandates decommissioning requirements overseen by local city or county governments. Oversight and enforcement authority may be delegated to local government entities or shared between state and local government. Localities must follow state decommissioning policies enacted through statute or regulation; however, they may prescribe additional decommissioning requirements that are more stringent than the state requirements. California and Illinois require solar facility owners to submit decommissioning plans and proof of financial assurance to local jurisdictional entities based on facility location. By contrast, Hawaii mandates solar facility owners comply with state decommissioning requirements (e.g., removal of system equipment) and submit proof of financial assurance to local jurisdictions based on facility location, but the state policy does not mandate the submission of a decommissioning plan. New Jersey and Wyoming require solar facility owners to submit decommissioning plans, without financial assurance to local entities based on the facility location or operating capacity. Nebraska and Oklahoma state policies require solar facility owners to provide a description of local decommissioning and financial assurance requirements within solar easements. Virginia has a statewide requirement that local jurisdictional solar facility siting ordinances include decommissioning and financial assurance requirements. Table 9 describes the threshold for hybrid state/local solar decommissioning policies and provides a summary of the requirements.

\section{Table 9. Regulatory Threshold for Hybrid State/Local Solar Decommissioning Policies and Summary of Requirements}

\begin{tabular}{|l|l|}
\hline State & Regulatory Threshold and Summary of Requirements \\
\hline California & $\begin{array}{l}\text { In California, as a condition for a self-renewing Solar Use Easement, } \\
\text { solar use easement project }{ }^{83} \text { located on land subject to the Williamson Act or farmland }\end{array}$ \\
\hline
\end{tabular}

\footnotetext{
${ }^{82}$ Solar-use easement means any right or interest acquired by a county, or city in perpetuity, for a term of years, or annually self-renewing as provided in Section 51191.2, in a parcel or parcels determined by the Department of Conservation pursuant to Section 51191 to be eligible, where the deed or other instrument granting the right or interest imposes restrictions that, through limitation of future use, will effectively restrict the use of the land to photovoltaic solar facilities for the purpose of providing for the collection and distribution of solar energy for the generation of electricity, and any other incidental or subordinate agricultural, open-space uses, or other alternative renewable energy facilities. A solar-use easement shall not permit any land located in the easement to be used for any other use allowed in commercial, industrial, or residential zones. A solar-use easement shall contain a covenant with the county, or city running with the land, either in perpetuity or for a term of years, that the landowner shall not construct or permit the construction of improvements except those for which the right is expressly reserved in the instrument provided that those reservations would not be inconsistent with the purposes of this chapter and which would not be incompatible with the sole use of the property for solar photovoltaic facilities (Cal. Gov. Code $\S 51190(\mathrm{c}))$.

${ }^{83}$ In California, a "solar use easement project" means all land and photovoltaic panels and foundations, and other installations, facilities, buildings, accessory structures, or other improvements to the land that are related to the
} 


\begin{tabular}{|l|l|}
\hline State & Regulatory Threshold and Summary of Requirements \\
\hline & $\begin{array}{l}\text { security zone contract must submit a decommissioning plan and financial assurance to } \\
\text { the local city or county government with jurisdiction prior to construction. The local city } \\
\text { or county government submits the solar use easement application, decommissioning } \\
\text { plan, and financial assurance documents to the California Department of Conservation } \\
\text { for final review and approval. The owner must review and resubmit the financial } \\
\text { assurance instrument to the local government every } 5 \text { years. }\end{array}$ \\
\hline Hawaii & $\begin{array}{l}\text { In Hawaii, as a condition of a Special Use Permit, the owner of a solar energy facility }{ }^{85} \\
\text { located on agricultural lands with a soil productivity rating of B or C must comply with } \\
\text { state decommissioning requirements and submit proof of financial assurance to the } \\
\text { local county planning commission with jurisdiction prior to construction. The local county } \\
\text { planning commission must submit all special use permit application documents, } \\
\text { including financial assurance documents, to the Hawaii Land Use Commission. }\end{array}$ \\
\hline Illinois & $\begin{array}{l}\text { In Illinois, the owner of a commercial renewable energy facility } \\
\text { land located on agricultural } \\
\text { lanned by a third party must enter into an Agricultural Impact Mitigation Agreement } \\
\text { with the Department of Agriculture outlining facility construction and deconstruction } \\
\text { plans and submit a deconstruction plan and financial assurance to the county } \\
\text { government with jurisdiction prior to construction. The owner must review and resubmit } \\
\text { the decommissioning plan, including the cost estimate and financial assurance } \\
\text { instrument to the county with jurisdiction } 10 \text { years after commercial operation } \\
\text { commences. }{ }^{88}\end{array}$ \\
\hline Nebraska & $\begin{array}{l}\text { In Nebraska, the owner of a solar energy system } \\
\text { (e.g., easement) to secure a land right for a solar energy system must include within the } \\
\text { solar agreement instrument a description of any decommissioning plans or financial } \\
\text { assurance instruments required by the local jurisdiction where the solar energy system } \\
\text { is located. }{ }^{90}\end{array}$ \\
\hline
\end{tabular}

photovoltaic generation of electricity on land that is or has been proposed to be placed in a solar-use easement (Cal. Code Regs. tit. 14 § 3101).

${ }^{84}$ Cal. Code Regs. tit. $14 \S \S 3102,3108,3111$

${ }^{85}$ In Hawaii, the Land Use Commission's regulations use the term "solar energy facility;" however, that term is undefined within the regulations.

${ }^{86}$ Haw. Rev. Stat. 205-4.5(21); 205-6

${ }^{87}$ In Illinois, "commercial renewable energy facility" means a commercial solar energy conversion facility with a capacity equal to or greater than $500 \mathrm{~kW}$ or a wind energy facility conversion facility with a capacity equal to or greater than $500 \mathrm{~kW}(505$ Ill. Comp. Stat. 147/10 (2018)).

88505 Ill. Comp. Stat. 147/15 (2018).

${ }^{89}$ In Nebraska, "solar energy system" means a complete design or assembly consisting of a device used primarily to transform solar energy into thermal, chemical, or electrical energy, an energy storage facility, and components for the distribution of transformed energy to the extent that they cannot be used jointly with a conventional energy system (Neb. Rev. Stat. § 66.905).

${ }^{90}$ Neb. Rev. Stat. $\S 66.911-01$ 


\begin{tabular}{|c|c|}
\hline State & Regulatory Threshold and Summary of Requirements \\
\hline New Jersey & $\begin{array}{l}\text { In New Jersey, as a condition of approval for a Site Plan, an owner of a solar energy } \\
\text { generation facility }{ }^{91} \text { located on commercial farmland subject to the Right to Farm Act }{ }^{92} \\
\text { must submit a conservation plan that addresses the impacts of decommissioning to the } \\
\text { local soil conservation district with jurisdiction. The Site Plan is subject to approval from } \\
\text { the New Jersey State Agriculture Development Committee. }{ }^{93} \text { In addition, an owner of a } \\
\text { solar energy generation facility located in a Pinelands Management Area must submit a } \\
\text { landscaping plan to the New Jersey Pinelands Commission that addresses the impacts } \\
\text { of decommissioning. } .^{94} \mathrm{New} \text { Jersey does not require proof of financial assurance at a } \\
\text { state level for solar facility decommissioning, but localities may impose financial } \\
\text { assurance requirements. }\end{array}$ \\
\hline Oklahoma & $\begin{array}{l}\text { In Oklahoma, a solar energy conversion system owner }{ }^{95} \text { who executes a Solar } \\
\text { Agreement (e.g., easement) to secure a land right for a solar energy conversion system } \\
\text { must include within the solar agreement instrument, a description of any } \\
\text { decommissioning plans or financial assurance instruments required by the local } \\
\text { jurisdiction where the energy facility is located. }{ }^{96}\end{array}$ \\
\hline Virginia & $\begin{array}{l}\text { In Virginia, the state legislature requires local governments with solar facility siting } \\
\text { ordinances to include solar decommissioning requirements within their regulations. } \\
\text { Local governments must require owners of solar energy equipment, facilities, or } \\
\text { devices }{ }^{97} \text { to submit decommissioning plans and proof of financial assurance to the local } \\
\text { entity with jurisdiction. }{ }^{98}\end{array}$ \\
\hline Wyoming & $\begin{array}{l}\text { In Wyoming, as a condition of approval for an Operating Permit, the owner of a solar } \\
\text { energy facility }{ }^{99} \text { with a capacity of greater than } 500 \mathrm{~kW} \text { must submit a decommissioning } \\
\text { plan to the county board of commissioners with jurisdiction prior to construction of the } \\
\text { facility. The solar facility owner must submit updated decommissioning plans every } 5 \\
\text { years until site reclamation and decommissioning is complete. Wyoming does not } \\
\text { require proof of financial assurance for energy facility decommissioning. }{ }^{100}\end{array}$ \\
\hline
\end{tabular}

${ }^{91}$ In New Jersey, "solar energy generation facility" means all the components of a solar generation system, including but not limited to structures and equipment, photovoltaic panels and films, arrays, collectors, piping, footings, supports, mounting and stabilization devices, inverters, pumps, transformers, electrical distribution and transmission wires, utility poles and other on-farm infrastructure necessary to operate and maintain the system for the generation of power or heat (N.J. Admin Code § 2:76-2A.12).

${ }^{92}$ Commercial farmland means a "farm management unit of no less than five acres producing agricultural or horticultural products worth $\$ 2,500$ or more annually, and satisfying the eligibility criteria for differential property taxation pursuant to the Farmland Assessment Act of 1964" or a "farm management unit less than five acres, producing agricultural or horticultural products worth $\$ 50,000$ or more annually and otherwise satisfying the eligibility criteria for differential property taxation pursuant to the Farmland Assessment Act of 1964" (N.J. Admin Code $\S 2: 76-2$ A.12(a)).

${ }^{93}$ N.J. Admin Code $§ 2: 76-2$ A. 12

${ }^{94}$ N.J. Admin Code $§ 7: 50-5.36$

${ }^{95}$ In Oklahoma, the Airspace Severance Restriction Act (Act), which governs conditions of solar agreements, refers to "solar energy conversion systems;" however, this term is not defined within the act (Okla. Stat. tit. 60, § 820.1).

${ }^{96}$ Okla. Stat. tit. $60, \S 820.1$

${ }^{97}$ In Virginia, "solar energy equipment, facilities, or devices" means any personal property designed and used primarily for the purpose of collecting, generating, or transferring electric energy from sunlight (Va. Code Ann. $\S 15.2-2241.2)$.

${ }_{98}$ Va. Code Ann. §15.2-2241.2; Va. Admin. Code § 67-103

${ }^{99}$ In Wyoming, a "solar energy facility" means a commercial facility with a rated power capacity of more than onehalf megawatt of electricity from solar power that includes all lands where the owner or developer has rights to erect solar energy facilities (Wyo. Stat. Ann. § 18-5-501).

${ }^{100}$ Wyo. Stat. Ann. $\S \S 18-5-501,18-5-503$ 


\subsection{Hybrid State/Local Solar Decommissioning Plan and/or Performance Requirements}

Hybrid state/local solar decommissioning policies vary by jurisdiction but often require the submission of a decommissioning plan, that incorporates site reclamation and restoration details, as well as a cost estimate to a state or local regulatory entity. By contrast, a few hybrid state/local solar decommissioning policies only mandate performance of specified decommissioning activities (e.g., removal of all solar system equipment) but do not require submission of a plan to state or local regulatory entities. Four states (California, Hawaii, New Jersey, and Wyoming) have hybrid state/local solar decommissioning policies that mandate decommissioning plans and/or performance requirements. One state, Virginia, has a hybrid state/local solar decommissioning policy that mandates solar facility owners enter into an agreement regarding decommissioning performance requirements with local entities with jurisdiction. Only Illinois and Virginia require facility owners provide cost estimates to local entities with jurisdiction. Notably, three of the jurisdictions with hybrid state/local decommissioning policies (Hawaii, Illinois, and New Jersey) impose timeframes on facility owners that dictate when decommissioning activities must be complete. Nebraska and Oklahoma do not have specific statewide decommissioning plan requirements but instead require compliance with local government rules and regulations. Table 10 summarizes hybrid state/local decommissioning plan and performance requirements in California, Hawaii, Illinois, Nebraska, New Jersey, Oklahoma, Virginia, and Wyoming.

Table 10. Hybrid State/Local Solar Decommissioning Plan and Performance Requirements

\begin{tabular}{|l|l|}
\hline State & Plan and Performance Requirements \\
\hline California & $\begin{array}{l}\text { State law requires that an owner submit a decommissioning plan to the local city or } \\
\text { county government with jurisdiction that includes the following information: } \\
\text { - Soil management plan } \\
\text { - Site restoration plan } \\
\text { - }\end{array}$ \\
\hline Hawaii & $\begin{array}{l}\text { State law requires removal all equipment within } 12 \text { months after operations cease and } \\
\text { restore the land to its preconstruction condition. }{ }^{102} \text { State law does not require submittal } \\
\text { of a decommissioning plan; however, local regulations may apply. }\end{array}$ \\
\hline Illinois & $\begin{array}{l}\text { State law requires that an owner submit a decommissioning plan to the local city or } \\
\text { county government with jurisdiction addressing the following: } \\
\text { - Restoration of agricultural land to pre-construction state } \\
\text { - Removal of aboveground structures (supports, facilities, wires, anchors, access }\end{array}$ \\
& $\begin{array}{l}\text { - Reads) } \\
\text { - Topsoil removal and replacement } \\
\text { - } \quad \text { A detailed decommissioning cost estimate. }{ }^{103}\end{array}$ \\
\hline
\end{tabular}

${ }^{101}$ Cal. Code Regs. tit. $14 \S 3108$

${ }^{102}$ Haw. Rev. Stat. 205-4.5(21)

${ }^{103}$ Illinois Department of Agriculture. 2019. "Standard Agricultural Mitigation Agreement Form." https://www2.illinois.gov/sites/agr/Resources/AIMA/Documents/Std\%20Solar\%20AIMA.pdf. 


\begin{tabular}{|c|c|}
\hline State & Plan and Performance Requirements \\
\hline Nebraska & $\begin{array}{l}\text { State law requires that an owner describe any decommissioning plan required by the } \\
\text { local government with jurisdiction within the solar easement. } 104\end{array}$ \\
\hline New Jersey & $\begin{array}{l}\text { State law requires the owner of a solar facility on commercial farmland submit a } \\
\text { conservation plan to the local soil conservation district with jurisdiction addressing: } \\
\text { - Removal of the solar facility within } 18 \text { months after operations have ceased } \\
\text { - Restoration of the land to achieve agricultural productivity. }{ }^{105} \\
\text { State law requires the owner of a solar facility located in a Pinelands Management Area } \\
\text { must submit a landscaping or revegetation plan to the New Jersey Pinelands } \\
\text { Commission addressing removal of all solar facility structures and equipment within } 12 \\
\text { months after operations cease. }{ }^{106}\end{array}$ \\
\hline Oklahoma & $\begin{array}{l}\text { State law requires that an owner describe any decommissioning plan required by the } \\
\text { local government with jurisdiction within the solar easement. } 107\end{array}$ \\
\hline Virginia & $\begin{array}{l}\text { State law requires the owner enter into a written agreement with the locality with } \\
\text { jurisdiction to decommission the solar energy equipment, facilities, and devices within a } \\
\text { specified timeframe as well as detailed cost estimate prepared by a professional } \\
\text { engineer licensed in Virginia. }{ }^{108}\end{array}$ \\
\hline Wyoming & $\begin{array}{l}\text { State law requires the owner submit a decommissioning plan to the county board of } \\
\text { commissioners with jurisdiction addressing how the solar facility will be } \\
\text { decommissioned and reclaimed at the end of the facility's life. }{ }^{109}\end{array}$ \\
\hline
\end{tabular}

As noted above, only 2 of the 8 states with hybrid state/local solar decommissioning policies, Illinois and Virginia, mandate that solar project developers submit a cost estimate for decommissioning the solar facility to local entities with jurisdiction. The specifications regarding what must be included or excluded within the cost estimate vary by state and neither Illinois nor Virginia requires a specific calculation method at the state level; however, local regulations may mandate specific cost estimate calculation methods. California, Hawaii, Nebraska, New Jersey, Oklahoma, and Wyoming do not mandate that decommissioning plans include a cost estimate at the state level; however, local regulations may mandate that facility owners provide decommissioning cost estimates. Table 11 summarizes cost estimate requirements in California, Hawaii, Illinois, Nebraska, New Jersey, Oklahoma, Virginia, and Wyoming.

Table 11. Hybrid State/Local Solar Decommissioning Cost Requirements

\begin{tabular}{|l|l|}
\hline State & Cost Requirements \\
\hline California & Not prescribed by state statute or regulation but local requirements may apply. \\
\hline Hawaii & Not prescribed by state statute or regulation but local requirements may apply. \\
\hline
\end{tabular}

${ }^{104}$ Neb. Rev. Stat. $\S 66.911-01$

105 N.J. Admin Code $\S$ 2:76-2A.12

106 N.J. Admin Code $\S 7: 50-5.36$

${ }^{107}$ Okla. Stat. tit. 60, $\S 820.1$

${ }^{108}$ Va. Code Ann. §15.2-2241.2; Va. Admin. Code $§ 67-103$

109 Wyo. Stat. Ann. $§ 18-5-503$ 


\begin{tabular}{|c|c|}
\hline State & Cost Requirements \\
\hline Illinois & $\begin{array}{l}\text { Owner must submit a cost estimate prepared by a professional engineer licensed in } \\
\text { Illinois. The cost estimate must consider: } \\
\text { - The number of solar panels, racking, and related facilities } \\
\text { - The original construction costs } \\
\text { - Size and capacity of the facility } \\
\text { - Salvage value of the facility }{ }^{110}\end{array}$ \\
\hline Nebraska & Not prescribed by state statute or regulation but local requirements may apply. \\
\hline New Jersey & Not prescribed by state statute or regulation but local requirements may apply. \\
\hline Oklahoma & Not prescribed by state statute or regulation but local requirements may apply. \\
\hline Virginia & $\begin{array}{l}\text { Owner must submit a cost estimate prepared by a professional engineer licensed in } \\
\text { Virginia. The cost estimate: } \\
\text { - Must not exceed the total projected cost of decommissioning } \\
\text { - May include the salvage value of equipment, facilities, or devices } \\
\text { - May include an annual inflation factor. } \\
\text { Check local regulations for additional requirements. }{ }^{111}\end{array}$ \\
\hline Wyoming & Not prescribed by state statute or regulation but local requirements may apply. \\
\hline
\end{tabular}

\subsection{Financial Assurance Requirements}

Four states (California, Hawaii, Illinois, and Virginia) have hybrid state/local policies that mandate that solar developers submit financial assurance to a state and/or local entities to ensure funds will be available for decommissioning and site restoration. In addition, California requires facility owners to review and resubmit financial assurance to the local jurisdiction with authority every 5 years. Nebraska and Oklahoma do not have statewide financial assurance requirements, but they do require compliance with local financial assurance requirements. New Jersey and Wyoming do not require proof of financial assurance. Local and municipal governments may have financial assurance requirements in addition to state requirements. Table 12 summarizes hybrid state/local financial assurance requirements in California, Hawaii, New Jersey, Wyoming, Nebraska, Oklahoma, and Virginia.

Table 12. Hybrid State/Local Financial Assurance Requirements

\begin{tabular}{|l|l|l|l|l|}
\hline State & $\begin{array}{l}\text { Financial } \\
\text { Assurance }\end{array}$ & Date Due & Instrument Type & $\begin{array}{l}\text { Calculation Methods, } \\
\text { Contents, and } \\
\text { Amounts }\end{array}$ \\
\hline California $^{112}$ & Yes & $\begin{array}{l}\text { Prior to receiving a self- } \\
\text { renewing easement/prior } \\
\text { to construction }\end{array}$ & $\begin{array}{l}\text { Performance } \\
\text { bond }\end{array}$ & $\begin{array}{l}\text { The amount is based } \\
\text { on: }\end{array}$ \\
\hline
\end{tabular}

\footnotetext{
${ }^{110}$ Illinois Department of Agriculture. 2019. "Standard Agricultural Mitigation Agreement Form." https:/www2.illinois.gov/sites/agr/Resources/AIMA/Documents/Std\%20Solar\%20AIMA.pdf.

${ }^{111}$ Va. Code Ann. §15.2-2241.2; Va. Admin. Code $§ 67-103$

${ }^{112}$ Cal. Code Regs. tit. $14 \S 3111$
} 


\begin{tabular}{|c|c|c|c|c|}
\hline State & $\begin{array}{l}\text { Financial } \\
\text { Assurance }\end{array}$ & Date Due & Instrument Type & $\begin{array}{l}\text { Calculation Methods, } \\
\text { Contents, and } \\
\text { Amounts }\end{array}$ \\
\hline & & & & $\begin{array}{l}\text { - Costs of site } \\
\text { restoration and } \\
\text { reclamation as set } \\
\text { forth in the } \\
\text { decommissioning } \\
\text { plan (see Table 6) } \\
\text { - Costs of } \\
\text { equipment, } \\
\text { transportation, and } \\
\text { labor necessary for } \\
\text { infrastructure } \\
\text { removal } \\
\text { - Liability insurance } \\
\text { the owner is } \\
\text { required to } \\
\text { maintain for the } \\
\text { duration of } \\
\text { decommissioning } \\
\text { and restoration } \\
\text { work } \\
\text { Contingency } \\
\text { amount not to } \\
\text { exceed } 10 \% \text { of the } \\
\text { costs of site } \\
\text { restoration, which } \\
\text { does not include } \\
\text { construction and } \\
\text { operation costs } \\
\text { The amount must be } \\
\text { reviewed and } \\
\text { resubmitted to the } \\
\text { local government for } \\
\text { approval every } 5 \\
\text { years. }\end{array}$ \\
\hline Hawaii ${ }^{113}$ & Yes & Prior to operation & $\begin{array}{l}\text { Not prescribed by } \\
\text { state statute or } \\
\text { regulation; check } \\
\text { local regulations }\end{array}$ & $\begin{array}{l}\text { Not prescribed by } \\
\text { state statute or } \\
\text { regulation; check local } \\
\text { regulations }\end{array}$ \\
\hline Illinois ${ }^{114}$ & Yes & $\begin{array}{l}\text { Owner must submit: } \\
\text { - } 10 \% \text { before the end } \\
\text { of the first year of } \\
\text { operation }\end{array}$ & $\begin{array}{l}\text { Reclamation or } \\
\text { surety bond, or } \\
\text { other financial } \\
\text { instrument } \\
\text { acceptable to the }\end{array}$ & $\begin{array}{l}\text { The financial } \\
\text { assurance must be } \\
\text { based on the cost } \\
\text { estimate as set forth } \\
\text { within the }\end{array}$ \\
\hline
\end{tabular}

${ }^{113}$ Haw. Rev. Stat. 205-4.5(21)

114505 Ill. Comp. Stat. 147/15; Illinois Department of Agriculture. 2019. "Standard Agricultural Mitigation

Agreement Form." https://www2.illinois.gov/sites/agr/Resources/AIMA/Documents/Std\%20Solar\%20AIMA.pdf. 


\begin{tabular}{|c|c|c|c|c|}
\hline State & $\begin{array}{l}\text { Financial } \\
\text { Assurance }\end{array}$ & Date Due & Instrument Type & $\begin{array}{l}\text { Calculation Methods, } \\
\text { Contents, and } \\
\text { Amounts }\end{array}$ \\
\hline & & $\begin{array}{l}\text { - } 50 \% \text { before the end } \\
\text { of the sixth year of } \\
\text { operation } \\
\text { - } 100 \% \text { before the } \\
\text { eleventh year of } \\
\text { operation. }\end{array}$ & $\begin{array}{l}\text { county with } \\
\text { jurisdiction }\end{array}$ & $\begin{array}{l}\text { decommissioning plan } \\
\text { (see Table 9) }\end{array}$ \\
\hline Nebraska & $\begin{array}{l}\text { State law } \\
\text { mandates } \\
\text { compliance } \\
\text { with local } \\
\text { financial } \\
\text { assurance } \\
\text { requirements } \\
115\end{array}$ & $\mathrm{~N} / \mathrm{A}$ & $\mathrm{N} / \mathrm{A}$ & $\mathrm{N} / \mathrm{A}$ \\
\hline New Jersey & $\begin{array}{l}\text { No state-level } \\
\text { requirements } \\
\text { but local } \\
\text { regulations } \\
\text { may apply }\end{array}$ & $\mathrm{N} / \mathrm{A}$ & $\mathrm{N} / \mathrm{A}$ & $\mathrm{N} / \mathrm{A}$ \\
\hline Oklahoma & $\begin{array}{l}\text { State law } \\
\text { mandates } \\
\text { compliance } \\
\text { with local } \\
\text { financial } \\
\text { assurance } \\
\text { requirements } \\
116\end{array}$ & $\mathrm{~N} / \mathrm{A}$ & $\mathrm{N} / \mathrm{A}$ & $\mathrm{N} / \mathrm{A}$ \\
\hline Virginia $^{117}$ & Yes & Prior to construction & $\begin{array}{l}\text { - } \text { Bond } \\
\text { - } \text { Letter of credit } \\
\text { - Guarantee } \\
\text { - } \text { Certified fund } \\
\text { - } \text { Cash Escrow }\end{array}$ & $\begin{array}{l}\text { The financial } \\
\text { assurance must be } \\
\text { based on the cost } \\
\text { estimate as set forth } \\
\text { within the } \\
\text { decommissioning plan } \\
\text { (see Table 9). }\end{array}$ \\
\hline Wyoming & $\begin{array}{l}\text { No state-level } \\
\text { requirements } \\
\text { but local } \\
\text { regulations } \\
\text { may apply }\end{array}$ & $N / A$ & $\mathrm{~N} / \mathrm{A}$ & $N / A$ \\
\hline
\end{tabular}

115 The solar facility owner must describe any financial assurance instrument required by the local government where the facility is located as a condition of a solar agreement (easement) (Neb. Rev. Stat. § 66.911-01).

${ }_{116}$ The solar facility owner must describe any financial assurance instrument required by the local government where the facility is located as a condition of a solar agreement (easement) (Okla. Stat. tit. 60, § 820.1).

${ }^{117}$ Va. Code Ann. §15.2-2241.2 


\subsection{Hybrid State/Local Solar Decommissioning Policies Oversight Authority and Penalties}

California, Hawaii, Illinois, Nebraska, Oklahoma, Virginia, and Wyoming delegate oversight authority of solar decommissioning policies to local entities that may have the authority to assess penalties for noncompliance. In New Jersey, state regulatory entities retain authority to enforce decommissioning policies. Penalties vary by jurisdiction; however, in Hawaii and Wyoming, local authorities have the right to assess fines for noncompliance with state and local decommissioning policies. In addition, in California, noncompliance with decommissioning policies may result in forfeiture of financial assistance. In Virginia, local authorities have the right to enter property without consent and begin decommissioning in the event of noncompliance with decommissioning policies. Table 13 summarizes oversight authority and penalties.

Table 13. Oversight Authority and Penalties

\begin{tabular}{|c|c|c|}
\hline State & Enforcement Authority & Penalties for Noncompliance \\
\hline California & Local city or county government ${ }^{118}$ & Forfeiture of financial assurance ${ }^{119}$ \\
\hline Hawaii & Local county planning board ${ }^{120}$ & Fine of up to $\$ 5,000^{121}$ \\
\hline Illinois & Local jurisdiction $^{122}$ & Determined by the jurisdiction/variable \\
\hline Nebraska & Local jurisdiction $^{123}$ & Determined by the jurisdiction/variable \\
\hline New Jersey & $\begin{array}{l}\text { State Agriculture Development } \\
\text { Committee }{ }^{124} \text { or Pinelands } \\
\text { Commission }^{125}\end{array}$ & Civil action ${ }^{126}$ \\
\hline Oklahoma & Local jurisdiction $^{127}$ & Determined by the jurisdiction/variable \\
\hline Virginia & Local jurisdiction $^{128}$ & $\begin{array}{l}\text { Local jurisdictional entity may enter property } \\
\text { without consent and begin decommissioning }\end{array}$ \\
\hline Wyoming & County board of commissioners ${ }^{130}$ & Fine of up to $\$ 10,000 /$ day $^{131}$ \\
\hline
\end{tabular}

${ }^{118}$ Cal. Code Regs. tit. $14 \S 3111$

${ }^{119}$ Cal. Code Regs. tit. $14 \S 3111$

${ }^{120}$ Haw. Rev. Stat. 205-12

${ }^{121}$ Haw. Rev. Stat. 205-12

122505 Ill. Comp. Stat. 147/15.

${ }^{123}$ Neb. Rev. Stat. § 66.911-01

124 The State Agriculture Development Committee has authority and oversight over site plans for commercial farmland subject to the Right to Farm Act (N.J. Admin Code $\S \S 2: 76-2$ A.12(d)).

125 The New Jersey Pinelands Commission has authority and oversight over the construction, maintenance, and decommissioning of energy facilities on land designated as a Pinelands Management Area (N.J. Admin Code $\S$ 7:50-8.1).

${ }^{126}$ N.J. Admin Code $\S \S 2: 76-2 A .12$; N.J. Admin Code $\S 7: 50-8.1$

${ }^{127}$ Okla. Stat. tit. 60, $\S 820.1$

128 Va. Code Ann. §15.2-2241.2

${ }^{129}$ Va. Code Ann. $\$ 15.2-2241.2$

${ }^{130}$ Wyo. Stat. Ann. $§ 18-5-503$

131 Wyo. Stat. Ann. $§ 18-5-512$ 


\section{Optional State-level Decommissioning Requirements in Washington}

One state, Washington has enacted a voluntary state-level decommissioning policy.

Washington's policy allows solar facility developers to submit a decommissioning plan and proof of financial assurance to the State of Washington Energy Facility Site Evaluation Council (Council) in lieu of obtaining local and county government permits and approvals. In

Washington, as a condition of approval to enroll in the optional certification program, an energy facility owner must submit a site restoration plan and financial assurance to the Council prior to construction. $^{132}$

\subsection{Decommissioning Requirements}

An energy facility owner must submit a restoration plan to the Council 90 days prior construction that:

- Identifies, evaluates, and resolves all major environmental, public health, and public safety issues relevant to the site

- Describes the facility owner's methodology in choosing measures to be used to restore or preserve the site

- Compares economic factors of costs and benefits for different restoration options against any risks to the public. ${ }^{133}$

\subsection{Financial Assurance Requirements}

As part of the restoration plan, the facility owner must provide proof of financial security that (1) is sufficient to manage the restoration of the site and (2) includes evidence of pollution liability insurance coverage, and a site closure bond, sinking fund, or other financial instrument or security. The facility owner must also provide justifications for the amounts of the financial securities as proof that they will be sufficient to fund decommissioning and site restoration. ${ }^{134}$

\subsection{Oversight Authority and Penalties}

The Council has oversight and authority over decommissioning and financial assurance requirements. At least once every 5 years, an energy facility owner must review and submit an updated restoration plan that accounts for new conditions, technologies, and knowledge that could be relevant to facility decommissioning. ${ }^{135}$ Violations of the certification requirements may include penalties of $\$ 1,000-\$ 25,000$ per day. ${ }^{136}$

\footnotetext{
132 Wash. Rev. Code $\S \S 80.50 .020 ; 80.50 .060$; Wash. Admin. Code $\S 463-72-020$

${ }^{133}$ Wash. Admin. Code $\S 463-72-040$

${ }^{134}$ Wash. Admin. Code $\S 463-72-020$

${ }^{135}$ Wash. Admin. Code $\S 463-72-080$

136 Wash. Rev. Code $\S 80.50 .150$
} 


\section{Conclusion}

Our analysis found that U.S. solar decommissioning policies typically apply to utility-scale solar projects and can impact initial project development, system operations, system decommissioning and may influence equipment end-of-life management decisions. One federal agency, BLM, and 15 U.S. states have decommissioning policies in place that mandate compliance with requirements over the lifetime of the project. The development of solar decommissioning policies in the United States is expected to gain momentum as the call for utility-scale solar is projected to quadruple by 2030 to meet renewable energy and decarbonization goals. As of April 2021, five states (North Carolina, Maine, Pennsylvania, West Virginia, and Texas) have pending (not yet enacted) solar decommissioning regulations or legislation. ${ }^{137}$

The design of solar decommissioning policies is an important consideration for enabling responsible decommissioning practices and for solar deployment, project operations, and the overall U.S. solar market. Solar decommissioning policies can enable responsible system decommissioning practices but may also have unintended impacts on project development and project operations. These policies may include compliance with requirements that impact construction, pre-operation project timelines, and project operational costs that may affect project economics and/or initial project development decisions. Anecdotal evidence suggest that solar decommissioning policies can impact a project's initial development timelines and costs by mandating compliance with decommissioning requirements (e.g., submittal of decommissioning plans, cost estimates, and financial assurance) prior to approval of construction and siting applications, permits, and licenses. For instance, the complexity ${ }^{138}$ associated with decommissioning policy compliance may increase capital costs and extend construction timelines in jurisdictions that condition construction and site related approvals on submittal of decommissioning plans, financial assurance, and/or conformance with decommissioning performance requirements.

Some of the decommissioning policy designs we analyzed are arguably more favorable to solar project development than others (Maamari 2018; NYSERDA 2020). ${ }^{139}$ For example, our research found that solar decommissioning policies may dictate whether financial assurance must be provided at the outset of a project as a capital cost or may be provided later during project operation (Wyatt 2020; Maamari 2018; NYSERDA 2020). BLM, California, Hawaii, Louisiana, Minnesota, New Hampshire, North Dakota, Vermont, and Virginia all require submittal of financial assurance prior to project operation, increasing the capital costs to a solar project, which evidence suggests has led to prolonged construction timelines, delays, and even project cancellation (Maamari 2018; NYSERDA 2020). ${ }^{140}$ By contrast, some jurisdictions have enacted decommissioning policies that allow developers to submit financial assurance during project operation (e.g., in Montana, financial assurance must be provided before the end of the $15^{\text {th }}$ year

\footnotetext{
1372019 N.C. Sess. Laws 132, S.P. 113, 130th Leg., Reg. Sess. (Me. 2021), H.B. 1555, 205th Gen. Assemb., Reg. Sess. (Pa. 2021), S.B. 492, 2021 Leg., Reg. Sess. (W. Va. 2021), S.B. 760, 2021 Leg., Reg. Sess. (Tex. 2021).

${ }^{138}$ New Hampshire and North Dakota require decommissioning plans are prepared by a qualified, independent third party at the facility owner's expense (N.H. Rev. Stat. Ann. § 162-H:2, 7; N.D. Admin. Code §§ 69-09-10-01, 69-0910-06).

${ }^{139}$ Megan Day, National Renewable Energy Laboratory, email, October 19, 2020.

${ }^{140}$ Megan Day, National Renewable Energy Laboratory, email, October 19, 2020.
} 
of project operation) or in phases (e.g., in Illinois, $10 \%$ of the entire financial assurance amount must be provided before operation begins, $50 \%$ before the end of the $6^{\text {th }}$ year of operation, and $100 \%$ before the end of the $11^{\text {th }}$ year of operation). Accordingly, in these jurisdictions, financial assurance may be absorbed as an operating cost rather than an upfront capital cost.

Solar decommissioning policies that require a decommissioning cost estimate vary by jurisdiction and may also impact capital costs and/or operational costs of projects. For example, policies may mandate that certain costs be included or excluded in the overall decommissioning cost estimate. Three states - Montana, Illinois, and Virginia - allow project owners to offset the costs of decommissioning (e.g., costs of infrastructure removal, transportation and labor, disposal, liability insurance, site restoration and reclamation) with an estimated salvage value (e.g., recycling), which may lower the projected costs of decommissioning. By contrast, BLM, New Hampshire, North Dakota, and Vermont specify that the salvage value of solar facility infrastructure must be excluded from the cost estimate. ${ }^{141}$ In jurisdictions that do not allow for salvage value to be included in the overall solar decommissioning cost estimate, the result may be higher decommissioning estimates and therefore higher financial assurance amounts for the project (Curtis et al. Forthcoming). For example, a $200 \mathrm{MW}$ project in the United States required a decommissioning bond of approximately $\$ 16$ million, because the permitting authority did not allow salvage value to be considered in setting the financial assurance level to cover decommissioning costs. ${ }^{142}$ Assuming an annual bond rate of $1 \%$, bond payments for the example project would be $\$ 160,000$ per year, or $\$ 4.8$ million over 30 years. ${ }^{143}$ The debate around allowing salvage to be calculated in a cost estimate boils down to concerns about over-estimating the future value of recycled PV system materials and resale of PV equipment versus underestimating the cost to properly decommission and dispose of PV equipment in lieu of reuse and recycling options (Hawley 2017). Future study is needed to determine whether financial assurance requirements which are typically based on a cost estimate are adequate to support solar decommissioning activities or whether they exceed the costs and place an undue burden on developers. Moreover, future research could analyze whether decommissioning policies that allow solar developers to offset decommissioning costs with the estimated salvage value of EoL system equipment influence EoL management decisions (e.g., provide an incentive for recycling rather than landfill disposal).

State policies also vary in terms of calculation methods prescribed for determining the decommissioning cost estimate amount, which are typically used to calculate financial assurance. Four states - Illinois, New Hampshire, North Dakota, and Virginia - require that cost estimates are prepared by a qualified third-party (e.g., state licensed engineer). In addition, Montana and North Dakota require project owners provide a description of the cost estimate calculation method used, but do not prescribe a specific methodology. We did not find any guidance, studies, or publicly available cost models related to cost estimate calculation methods; however, evidence suggests that the calculation method used is an important factor in determining cost estimates, and that the lack of a consistent calculation method has resulted in highly variable net

\footnotetext{
${ }^{141}$ Some jurisdictions (e.g., Louisiana, Montana, Minnesota, Hawaii, Nebraska, New Jersey, Oklahoma, and Wyoming) do not address cost estimate calculation methods.

142 Parikhit Sinha, First Solar, personal communication, 2018.

${ }^{143}$ Parikhit Sinha, First Solar, personal communication, 2018.
} 
decommissioning cost estimates ( $\$ \mathrm{MW}$ ) (Curtis et al. Forthcoming). Development of a publicly available decommissioning cost model as well as further study of decommissioning cost estimates and decommissioning best practices could provide guidance to asset owners and operators to adequately plan and prepare for system decommissioning. Study of decommissioning cost estimates compared to actual costs could provide guidance to enable accurate and consistent cost estimates that are sufficient to cover the costs of decommissioning and do not exceed actual costs. Qualitative study has also found that there is a need for guidance and best practices for system decommissioning and EoL equipment management, which could, for example, aid developers in accurately determining salvage value for recycled and reused equipment and may enable sustainable EoL equipment management.

Penalties for violating solar decommissioning requirements, which provide a mechanism to ensure decommissioning is carried out in accordance with state policies and that land will be returned to its pre-construction uses and value also vary widely by jurisdiction. Some U.S. states that we analyzed require the forfeiture of financial assurance (e.g., California, North Dakota, and Louisiana), allow state agencies to enter property and begin decommissioning the project (i.e., Virginia), or impose fines that can range from $\$ 100$ per day (e.g., Vermont) to $\$ 10,000$ per day (e.g., Minnesota, New Hampshire, Washington, and Wyoming) for violations. By contrast, Oklahoma, Illinois, and Nebraska leave penalties for violating decommissioning requirements entirely to local government. Additional research could analyze how penalties associated with violations of decommissioning policies may impact stakeholder interests. For example, whether creditors are more confident in investing and providing financing in jurisdictions that impose penalties. In addition, new research could study whether penalties imposed for violations of decommissioning policies are protecting state and landowner interests and ensuring system decommissioning as well as land restoration and remediation.

Many of the solar decommissioning policies analyzed in this report were not designed with solar technologies in mind, or even for renewable energy technologies, but instead they have been adopted from - or adapted in whole or in part for inclusion in-decommissioning policies for fossil fuel generating technologies such as oil and gas. Future research could also examine whether decommissioning policies, which are not specifically tailored to solar energy facilities accurately reflect the risks associated with solar decommissioning. Decommissioning policies that are designed to consider solar project development, operations, and EoL considerations unique to solar technologies and those that balance development objectives with responsible decommissioning practices may be best suited to facilitate sustainable EoL management practices as well as solar energy development in the United States.

Decommissioning policies may also provide a framework for enabling a circular economy for solar materials. Although we found no U.S. federal or state solar decommissioning policy that dictates a particular EoL disposition for system equipment (e.g., recycling or disposal), solar decommissioning policies could include language that mandates or incentivizes the recycling of decommissioned solar equipment. Some solar industry experts have also indicated that decommissioning policies may be a preferred policy mechanism to encourage sustainable EoL management practices over other policy frameworks like manufacturer takeback requirements or universal solid waste designations for EoL solar PV modules (Curtis et al. 2021b, Curtis et al. 2021c). One reason that decommissioning policies may be favored to encourage recycling-based resource recovery of solar equipment is because the requirements of these policies are known at 
the outset of the project, prior to project construction or operation, allowing project owners time to plan well in advance for project decommissioning activities which could include a requirement to recycle EoL system equipment (Curtis et al. 2021b, Curtis et al. 2021c).

Although the scope of this report is limited to analysis of U.S. statewide and BLM solar decommissioning policies, ${ }^{144}$ future research could review other federal non-land management agencies that may have solar installations located on property or land under their jurisdiction (e.g., Bureau of Indian Affairs, Department of Defense) to identify decommissioning policies and provide an analysis of their requirements. In addition, future research could review local county and municipal regulations and ordinances in states that leave decommissioning requirements to local government. This additional solar decommissioning policy research could be coupled with analysis and predictive modeling that provides insight on how certain policy requirements influence project development, operations, system decommissioning, EoL management, and repowering decisions. For example, future research could analyze whether financial assurance and cost estimate requirements that lead to higher operating costs may also lead to higher insurance costs. In addition, future research could look at international PV system decommissioning policies to inform efforts in the United States.

\footnotetext{
${ }^{144}$ We also conducted a survey of the four major federal land management agencies (BLM, FS, FWS, and NPS) and determined that the BLM is currently the only major federal land management agency with a decommissioning policy. Accordingly, our analysis of federal decommissioning policies is limited to the BLM.
} 


\section{References}

Ayala, Silvana, Heather Mirletz, and Acadia Hegedus, 2021. NREL/PV_ICE: Release version 2. Zenodo. doi: 10.5281/zenodo.5196342.

Barbosa, Cesar. 2020. New Regulations for End-of-Life PV Modules California Solar and Storage Association. Webinar presentation, November 11, 2020. NuLife Power Services Inc.

Black's Law Dictionary (11th ed. 2019).

BLM (Bureau of Land Management). 2021. "Solar Energy.” Accessed April 29, 2021. https://www.blm.gov/programs/energy-and-minerals/renewable-energy/solar-energy.

. 2021. "Solar Energy Rights-Of-Way (ROW) on Public Lands." Accessed September 10, 2021. https://www.blm.gov/sites/blm.gov/files/docs/202105/PROJECT\%20LIST\%20SOLAR_May-2021..pdf.

. 2020 "Interior Approves Plan for the Largest Solar Project in U.S. History." Last updated May 11, 2020. https://www.doi.gov/pressreleases/interior-approves-plan-largest-solarproject-us-history

. 2018. "Right of Way Authorizations.” Last updated January 15, 2018. https://blmsolar.anl.gov/program/authorization-policies/row-authorizations/.

. 2017. "Solar Energy Program: Performance and Reclamation Bond." Last updated $\overline{\text { December 13, 2017. https://blmsolar.anl.gov/program/authorization-policies/bond/. }}$

- 2015. "Solar and Wind Energy Performance and Reclamation Bonds and Reclamation Cost Estimate Review Requirements.” Instruction Memorandum IM 2015-318. August 31, 2015. https://www.blm.gov/policy/im-2015-138.

CRS (Congressional Research Service). 2021. “The Federal Land Management Agencies.” Last updated February 16, 2021. https://fas.org/sgp/crs/misc/IF10585.pdf.

Curtis, Taylor L., Garvin Heath, Andy Walker, Jal Desai, Edward Settle, and Cesar Barbosa. 2021a. Best Practices at the End of Photovoltaic System Performance Period. Golden, CO:

National Renewable Energy Laboratory. NREL/TP-5C00-78678.

https://www.nrel.gov/docs/fy21osti/78678.pdf.

. 2021b. Curtis, Taylor L., Heather Buchanan, Garvin Heath, Ligia Smith, and Stephanie Shaw. 2021. Solar Photovoltaic Module Recycling: A Survey of U.S. Policies and Initiatives. Golden, CO: National Renewable Energy Laboratory. NREL/TP-6A20-74124. https://www.nrel.gov.docs/fy21osti/74124.

. 2021c. Curtis, Taylor L., Heather Buchanan, Ligia Smith, and Garvin Heath. 2021. A Circular Economy for Solar Photovoltaic System Materials: Drivers, Barriers, Enablers, and U.S. Policy Considerations. Golden, CO: National Renewable Energy Laboratory. NREL/TP6A20-74550. https://www.nrel.gov.docs/fy21osti/74550. 
Forthcoming. Curtis, Taylor L., Ligia Smith, Garvin Heath, and Jesse Carey. 2021. A Study of Solar Decommissioning Costs and Trends. Golden, Co: National Renewable Energy Laboratory. NREL/TP-6A20-81647.

Davis, Michelle, Bryan White, Colin Smith, Rachel Goldstein, Xiaojing Sun, Molly Cox, Gregson Curtin, et al. U.S. Solar Market Insight Report. Full Report 2020 Year in Review. March 2021a. Wood MacKenzie and Solar Energy Industries Association.

. 2021b. U.S. Solar Market Insight. Excel Data Q2 2021. June 2021. Wood MacKenzie and Solar Energy Industries Association.

EERA (Minnesota Department of Commerce Energy Environmental Review and Analysis Staff). 2020. EERA Recommendations on Review of Solar and Wind Decommissioning Plans.

Commission Docket Number E999/M-17-123. March 16, 2020.

https://www.edockets.state.mn.us/EFiling/edockets/searchDocuments.do?method=showPoup\&d ocumentId=\%7b1024E570-0000-CD11-98E8-4EC4D05E58E7\%7d\&documentTitle=20203$\underline{161292-01 .}$.

EIA (U.S. Energy Information Administration). 2019. "Most U.S. Utility-Scale Solar Photovoltaic Power Plants are 5 Megawatts or Smaller.” Today in Energy (February 7, 2019). https://www.eia.gov/todayinenergy/detail.php?id=38272.

Hawley, Jon. 2017. "Solar Decommissioning Rules Advance." The Daily Advance (August 8, 2017). http://www.dailyadvance.com/News/2017/08/08/County-approves.html

Heeter, Jenny. 2014. Status and Trends in the U.S. Voluntary Green Power Market (2013 Data). Golden, CO; National Renewable Energy Laboratory, NREL/TP-6!20-63052.

https://www.nrel.gov/docs/fy15osti/63052.pdf

Maamari, Lea. 2018. "Decommissioning of Solar Site: A Key Consideration of the Project." SolUnesco. September 10, 2018. https://solunesco.com/2018/09/10/decommissioning-of-solarsites-a-key-consideration-of-the-project/.

MDOC (Minnesota Department of Commerce). 2018. Solar and Wind Decommissioning Working Group: Report and Recommendations. MPUC Docket No. E-999/M-17-123. August 2018.

https://www.edockets.state.mn.us/EFiling/edockets/searchDocuments.do?method=showPoup\&d ocumentId=\%7BF0DC9065-0000-C734-8DCC-76C867A06CD8\%7D\&documentTitle=20188$\underline{146145-02 .}$.

Michigan Department of Environment, Great Lakes, and Energy. "Zoning for Renewable Energy Database." Michigan Department of Environment, Great Lakes, and Energy. Accessed December 9, 2020. https://www.michigan.gov/climateandenergy/0,4580,7-364-85453_85461519951--,00.html. 
NYSERDA (New York State Energy Research and Development Authority). 2020.

Decommissioning Solar Panel Systems: Information for Local Governments and Landowners on the Decommissioning of Large-Scale Solar Panel Systems. Albany, NY: NYSERDA.

https://www.nyserda.ny.gov/-/media/NYSun/files/Decommissioning-Solar-Systems.pdf.

Office of the Inspector General (OIG). 2012. "Bureau of Land Management's Renewable Energy Program: A Critical Point in Renewable Energy Development." Report No.: CR-EV-BLM-00042010. June 12, 2012. https://docs.wind-watch.org/BLM-Renewable-Energy-Program.pdf.

Ovaitt, Silvana, Heather Mirletz, Sridha Seetharaman, and Teresa Barnes, Forthcoming. "PV In the Circular Economy: A dynamic framework for impact analysis of technology evolution and reliability," iScience, Accepted.

Pivot Energy. 2017. "What Landowners Should Know About Solar Leases. September 22, 2017. https://www.pivotenergy.net/what-landowners-should-know-about-solar-land-leases/.

SEIA (Solar Energy Industries Association). 2021. "Siting, Permitting, and Land Use for UtilityScale Solar.” https://www.seia.org/initiatives/siting-permitting-land-use-utility-scale-solar.

Wyatt, Jessi. 2020. "Repowering and Decommissioning: What Happens in Communities When Solar and Wind Projects End." Great Plans Institute (April 1, 2020). https://www.betterenergy.org/blog/repowering-and-decommissioning-what-happens-incommunities-when-solar-and-wind-projects-end/.

\subsection{Federal and State Statutes and Legislative Materials}

Federal Land Policy and Management Act (FLPMA), 43 U.S.C. $§ \S 1701-1787$ (1976).

Cal. Gov. Code $§ 51190-91$.

Haw. Rev. Stat. 205-4.5(21), -13.

505 Ill. Comp. Stat. 147 (2018).

130th Leg., Reg. Sess. (Me. 2021)

Minn. Stat. $\S \S 216 E .001-216 E .18$.

Minn. R. 7854.0100 - 7854.1500.

2019 N.C. Sess. Laws 132

Neb. Rev. Stat. § 66.911-01.

N.H. Rev. Stat. Ann. § 162-H:2, 7, 12, 16, 19.

Okla. Stat. tit. $60, \S 820.1$.

H.B. 1555, 205th Gen. Assemb., Reg. Sess. (Pa. 2021) 
S.B. 760, 2021 Leg., Reg. Sess. (Tex. 2021)

Va. Code Ann. § 15.2-2241.2.

Wash. Rev. Code $\S 80.50 .060$.

S.B. 492, 2021 Leg., Reg. Sess. (W. Va. 2021)

Wyo. Stat. Ann. § 18-5-503.

\subsection{Federal and State Regulations}

Federal Land Policy and Management Act (FLPMA), 43 U.S.C. $\S \S 1701$ - 1787 (1976).

43 C.F.R. $\S \S 2800,2805,2880$.

Cal. Code Regs. tit. 14, §§ 3102, 3108, 3111.

La. Admin. Code tit. 43:V, §§ 921, 953-55, 961-69.

Mont. Admin. R. 17.86.102, 17.86.105-06, 17.86.110-112.

N.D. Admin. Code § 69-09-10-01, -06, -08-10.

N.H. Admin. R. Site 301.08(d)(2).

N.J. Admin Code § 2:76-2A.12(m).

N.J. Admin Code § 7:50-5.36(a)(4).

N.J. Admin Code § 7:50-8.1.

Va. Admin. Code § 67-103.

Vt. PUC Rule 5.900-907.

Wash. Admin. Code § 463-72-040, -020.

Wash. Rev. Code $\S 80.50 .150$. 


\section{A.1 Summary of BLM and State Policies Analyzed}

Table A-1 summarizes the BLM and 15 state decommissioning policies analyzed within the report.

Table A-1. Summary of BLM and State Policies Analyzed

\begin{tabular}{|c|c|c|c|c|c|c|c|}
\hline Jurisdiction & Policy Type & $\begin{array}{l}\text { Oversight } \\
\text { Authority }\end{array}$ & $\begin{array}{l}\text { Relationship to } \\
\text { Programs, } \\
\text { Certificates, } \\
\text { Permits, or Other } \\
\text { Approvals }\end{array}$ & $\begin{array}{l}\text { Summary of } \\
\text { Requirements }\end{array}$ & $\begin{array}{l}\text { Decommissioning } \\
\text { Plan Required by } \\
\text { Regulations }\end{array}$ & $\begin{array}{l}\text { Financial } \\
\text { Assurance } \\
\text { Required by } \\
\text { Regulations }\end{array}$ & $\begin{array}{l}\text { Cost } \\
\text { Estimate } \\
\text { Required by } \\
\text { Regulations }\end{array}$ \\
\hline BLM & Federal & BLM & $\begin{array}{l}\text { Requirement under } \\
\text { BLM's right-of-way } \\
\text { (ROW) program (43 } \\
\text { C.F.R. § } 2801.2 \text { - } \\
\text { 2809.19) }\end{array}$ & $\begin{array}{l}\text { A Performance and } \\
\text { Reclamation Bond for a } \\
\text { solar energy ROW covers } \\
\text { the decommissioning, } \\
\text { removal, and disposal of the } \\
\text { facility and equipment as } \\
\text { well as site reclamation, } \\
\text { revegetation, and } \\
\text { restoration costs (43 C.F.R. } \\
\S 2801.2 \text { - 2809.19). }\end{array}$ & Yes & Yes & $\begin{array}{l}\text { Yes; no less } \\
\text { than } \\
\$ 10,000 / a c r e\end{array}$ \\
\hline California & $\begin{array}{l}\text { Hybrid } \\
\text { state/local }\end{array}$ & $\begin{array}{l}\text { California } \\
\text { Department of } \\
\text { Conservation } \\
\text { and local city or } \\
\text { county } \\
\text { government }\end{array}$ & $\begin{array}{l}\text { Condition of approval } \\
\text { for a solar-use } \\
\text { easement (Cal. Gov. } \\
\text { Code } \S 51191.3 \text { ) }\end{array}$ & $\begin{array}{l}\text { In California, as a condition } \\
\text { for a self-renewing Solar } \\
\text { Use Easement, the owner } \\
\text { of a solar use easement } \\
\text { project on land subject to } \\
\text { the Williamson Act or } \\
\text { farmland security zone } \\
\text { contract must submit a } \\
\text { decommissioning plan and } \\
\text { financial assurance to the } \\
\text { local city or county } \\
\text { government with jurisdiction } \\
\text { prior to construction. The } \\
\text { local city or county } \\
\text { government submits the } \\
\text { solar use easement } \\
\text { application documents, } \\
\text { decommissioning plan, and } \\
\text { financial assurance } \\
\text { documents, to the California } \\
\text { Department of Conservation } \\
\text { (Department) for final } \\
\text { review and approval (Cal. } \\
\text { Code Regs. tit. } 14 \text { § } 3101) \text {. }\end{array}$ & Yes & Yes & No \\
\hline
\end{tabular}




\begin{tabular}{|c|c|c|c|c|c|c|c|}
\hline Jurisdiction & Policy Type & $\begin{array}{l}\text { Oversight } \\
\text { Authority }\end{array}$ & $\begin{array}{l}\text { Relationship to } \\
\text { Programs, } \\
\text { Certificates, } \\
\text { Permits, or Other } \\
\text { Approvals }\end{array}$ & $\begin{array}{l}\text { Summary of } \\
\text { Requirements }\end{array}$ & $\begin{array}{l}\text { Decommissioning } \\
\text { Plan Required by } \\
\text { Regulations }\end{array}$ & $\begin{array}{l}\text { Financial } \\
\text { Assurance } \\
\text { Required by } \\
\text { Regulations }\end{array}$ & $\begin{array}{l}\text { Cost } \\
\text { Estimate } \\
\text { Required by } \\
\text { Regulations }\end{array}$ \\
\hline Hawaii & $\begin{array}{l}\text { Hybrid } \\
\text { state/local }\end{array}$ & $\begin{array}{l}\text { County } \\
\text { Planning } \\
\text { Commission }\end{array}$ & $\begin{array}{l}\text { Condition of approval } \\
\text { for a special use } \\
\text { permit to operate a } \\
\text { solar facility on Class } \\
\text { B or C agricultural } \\
\text { land (HRS } \S 205-4.5 \text { ) }\end{array}$ & $\begin{array}{l}\text { In Hawaii, as a condition of } \\
\text { a Special Use Permit, the } \\
\text { owner of a solar energy } \\
\text { facility on agricultural lands } \\
\text { with a soil productivity rating } \\
\text { of B or C must comply with } \\
\text { state decommissioning } \\
\text { requirements and submit } \\
\text { proof of financial assurance } \\
\text { to the local county planning } \\
\text { commission with jurisdiction } \\
\text { prior to construction. The } \\
\text { local county planning } \\
\text { commission must submit all } \\
\text { special use permit } \\
\text { application documents, } \\
\text { including financial } \\
\text { assurance documents, to } \\
\text { the Hawaii State Land Use } \\
\text { Commission (Haw. Rev. } \\
\text { Stat. 205-4.5(21)). }\end{array}$ & No & Yes & No \\
\hline Illinois & $\begin{array}{l}\text { Hybrid } \\
\text { state/local }\end{array}$ & $\begin{array}{l}\text { County } \\
\text { government }\end{array}$ & $\begin{array}{l}\text { Required element of } \\
\text { an Agricultural Impact } \\
\text { Mitigation Agreement } \\
\text { (505 III. Comp. Stat. } \\
\text { 147/15 (2018)). }\end{array}$ & $\begin{array}{l}\text { In Illinois, the owner of a } \\
\text { commercial renewable } \\
\text { energy facility located on } \\
\text { agricultural land owned by a } \\
\text { third party must enter into } \\
\text { an Agricultural Impact } \\
\text { Mitigation Agreement with } \\
\text { the Department of } \\
\text { Agriculture outlining facility } \\
\text { construction and } \\
\text { deconstruction plans and } \\
\text { submit a deconstruction } \\
\text { plan and financial } \\
\text { assurance to the county } \\
\text { government with jurisdiction } \\
\text { prior to construction. The } \\
\text { owner must review and } \\
\text { resubmit the }\end{array}$ & Yes & Yes & Yes \\
\hline
\end{tabular}




\begin{tabular}{|c|c|c|c|c|c|c|c|}
\hline Jurisdiction & Policy Type & $\begin{array}{l}\text { Oversight } \\
\text { Authority }\end{array}$ & $\begin{array}{l}\text { Relationship to } \\
\text { Programs, } \\
\text { Certificates, } \\
\text { Permits, or Other } \\
\text { Approvals }\end{array}$ & $\begin{array}{l}\text { Summary of } \\
\text { Requirements }\end{array}$ & $\begin{array}{l}\text { Decommissioning } \\
\text { Plan Required by } \\
\text { Regulations }\end{array}$ & $\begin{array}{l}\text { Financial } \\
\text { Assurance } \\
\text { Required by } \\
\text { Regulations }\end{array}$ & $\begin{array}{l}\text { Cost } \\
\text { Estimate } \\
\text { Required by } \\
\text { Regulations }\end{array}$ \\
\hline & & & & $\begin{array}{l}\text { decommissioning plan, } \\
\text { including the cost estimate } \\
\text { and financial assurance } \\
\text { instrument to the county } \\
\text { with jurisdiction } 10 \text { years } \\
\text { after commercial operation } \\
\text { commences (505 III. Comp. } \\
\text { Stat. } 147 / 15(2018)) \text {. }\end{array}$ & & & \\
\hline Louisiana & State-level & $\begin{array}{l}\text { Louisiana } \\
\text { Department of } \\
\text { Natural } \\
\text { Resources }\end{array}$ & $\begin{array}{l}\text { Condition of approval } \\
\text { for an Alternative } \\
\text { Energy Source Lease } \\
\text { (AESL) to operate a } \\
\text { solar facility on state } \\
\text { land }\end{array}$ & $\begin{array}{l}\text { In Louisiana, as a condition } \\
\text { of approval for an AESL, the } \\
\text { owner of an alternative } \\
\text { energy source facility on } \\
\text { state land must submit a } \\
\text { decommissioning plan and } \\
\text { financial assurance to the } \\
\text { Louisiana Department of } \\
\text { Natural Resources } \\
\text { (Department) prior to } \\
\text { commencing } \\
\text { decommissioning activities. } \\
\text { Within } 60 \text { days of } \\
\text { completing } \\
\text { decommissioning activities, } \\
\text { the facility owner must notify } \\
\text { the Department and submit } \\
\text { a decommissioning report } \\
\text { that includes a summary of } \\
\text { decommissioning activities } \\
\text { and a description of any } \\
\text { mitigation measures utilized } \\
\text { during decommissioning } \\
\text { (La. Admin. Code tit. } 43: \mathrm{V} \text {, } \\
\S \S 921,961,967 \text { ). }\end{array}$ & Yes & $\begin{array}{l}\text { Yes; no less } \\
\text { than } \\
\$ 500,000\end{array}$ & No \\
\hline New Jersey & $\begin{array}{l}\text { Hybrid } \\
\text { state/local }\end{array}$ & $\begin{array}{l}\text { Local soil } \\
\text { conservation } \\
\text { district and } \\
\text { New Jersey }\end{array}$ & $\begin{array}{l}\text { Required for solar } \\
\text { energy facilities on } \\
\text { commercial farmland } \\
\text { seeking the benefits } \\
\text { and protections of the }\end{array}$ & $\begin{array}{l}\text { In New Jersey, as a } \\
\text { condition of approval for a } \\
\text { Site Plan, an owner of a } \\
\text { solar energy generation } \\
\text { facility on commercial }\end{array}$ & Yes & No & No \\
\hline
\end{tabular}




\begin{tabular}{|c|c|c|c|c|c|c|c|}
\hline Jurisdiction & Policy Type & $\begin{array}{l}\text { Oversight } \\
\text { Authority }\end{array}$ & $\begin{array}{l}\text { Relationship to } \\
\text { Programs, } \\
\text { Certificates, } \\
\text { Permits, or Other } \\
\text { Approvals }\end{array}$ & $\begin{array}{l}\text { Summary of } \\
\text { Requirements }\end{array}$ & $\begin{array}{l}\text { Decommissioning } \\
\text { Plan Required by } \\
\text { Regulations }\end{array}$ & $\begin{array}{l}\text { Financial } \\
\text { Assurance } \\
\text { Required by } \\
\text { Regulations }\end{array}$ & $\begin{array}{l}\text { Cost } \\
\text { Estimate } \\
\text { Required by } \\
\text { Regulations }\end{array}$ \\
\hline & & \begin{tabular}{|l|} 
Pinelands \\
Commission a
\end{tabular} & $\begin{array}{l}\text { Right to Farm Act or } \\
\text { located in a } \\
\text { Pinelands } \\
\text { Management Area } \\
\text { (N.J. Admin Code } \S \\
\text { 2:76-2A.12(m)) }\end{array}$ & $\begin{array}{l}\text { farmland subject to the } \\
\text { Right to Farm Act must } \\
\text { submit a conservation plan } \\
\text { that addresses the impacts } \\
\text { of decommissioning to the } \\
\text { soil conservation district } \\
\text { with jurisdiction. The site } \\
\text { plan is subject to approval } \\
\text { from the New Jersey State } \\
\text { Agriculture Development } \\
\text { Committee (N.J. Admin } \\
\text { Code } § 2: 76-2 A .12 \text { ). In } \\
\text { addition, an owner of a solar } \\
\text { energy generation facility } \\
\text { located in a Pinelands } \\
\text { Management Area must } \\
\text { submit a landscaping plan } \\
\text { that addresses the impacts } \\
\text { of decommissioning to the } \\
\text { Pinelands Commission (N.J. } \\
\text { Admin Code } § 7: 50-5.36 \text { ) }\end{array}$ & & & \\
\hline Minnesota & State-level & $\begin{array}{l}\text { Minnesota } \\
\text { Public Utilities } \\
\text { Commission }\end{array}$ & $\begin{array}{l}\text { Condition of a Site } \\
\text { License }\end{array}$ & $\begin{array}{l}\text { In Minnesota, as a condition } \\
\text { of a site license, the owner } \\
\text { of a large electric power } \\
\text { generating plant with a } \\
\text { capacity of } 50 \mathrm{MW} \text { or more } \\
\text { must submit a } \\
\text { decommissioning plan and } \\
\text { financial assurance to the } \\
\text { Minnesota PUC (Minn. Stat. } \\
\S \S 216 \mathrm{E} .01,216 \mathrm{E} .02 \text {; Minn. } \\
\text { R. } 7854.0500) \text {. }\end{array}$ & Yes & Yes & Yes \\
\hline
\end{tabular}




\begin{tabular}{|c|c|c|c|c|c|c|c|}
\hline Jurisdiction & Policy Type & $\begin{array}{l}\text { Oversight } \\
\text { Authority }\end{array}$ & $\begin{array}{l}\text { Relationship to } \\
\text { Programs, } \\
\text { Certificates, } \\
\text { Permits, or Other } \\
\text { Approvals }\end{array}$ & $\begin{array}{l}\text { Summary of } \\
\text { Requirements }\end{array}$ & $\begin{array}{l}\text { Decommissioning } \\
\text { Plan Required by } \\
\text { Regulations }\end{array}$ & $\begin{array}{l}\text { Financial } \\
\text { Assurance } \\
\text { Required by } \\
\text { Regulations }\end{array}$ & $\begin{array}{l}\text { Cost } \\
\text { Estimate } \\
\text { Required by } \\
\text { Regulations }\end{array}$ \\
\hline Montana & State-level & $\begin{array}{l}\text { Montana } \\
\text { Department of } \\
\text { Environmental } \\
\text { Quality }\end{array}$ & $\mathrm{N} / \mathrm{A}$ & $\begin{array}{l}\text { In Montana, the owner of a } \\
\text { facility with a capacity of } 2 \\
\text { MW or greater must submit } \\
\text { (1) a decommissioning plan } \\
\text { within } 12 \text { months prior to } \\
\text { operation of the facility and } \\
\text { (2) financial assurance at } \\
\text { any time prior to } 15^{\text {th }} \text { year of } \\
\text { the facility's operation to the } \\
\text { Montana Department of } \\
\text { Environmental Quality } \\
\text { (Mont. Admin. R. } 17.86 .102 \text {, } \\
\text { 17.86.105). }\end{array}$ & Yes & Yes & Yes \\
\hline Nebraska & $\begin{array}{l}\text { Hybrid } \\
\text { state/local }\end{array}$ & $\begin{array}{l}\text { Delegated to } \\
\text { local } \\
\text { government }\end{array}$ & $\begin{array}{l}\text { An owner of a solar } \\
\text { energy facility subject } \\
\text { to a solar easement } \\
\text { is required to submit } \\
\text { a description of } \\
\text { decommissioning } \\
\text { plans that address } \\
\text { any local } \\
\text { regulations/requireme } \\
\text { nts. }\end{array}$ & $\begin{array}{l}\text { In Nebraska, the owner of a } \\
\text { solar energy system who } \\
\text { executes a solar agreement } \\
\text { (e.g., easement) to secure a } \\
\text { land right for a solar energy } \\
\text { system must include within } \\
\text { the solar agreement } \\
\text { instrument, a description of } \\
\text { any decommissioning plans } \\
\text { or financial assurance } \\
\text { instruments required by the } \\
\text { local jurisdiction where the } \\
\text { solar energy system is } \\
\text { located (Neb. Rev. Stat. } \S \\
66.911-01) \text {. }\end{array}$ & $\begin{array}{l}\text { No; check local } \\
\text { ordinances }\end{array}$ & $\begin{array}{l}\text { No; check } \\
\text { local } \\
\text { ordinances }\end{array}$ & $\begin{array}{l}\text { No; check } \\
\text { local } \\
\text { ordinances }\end{array}$ \\
\hline $\begin{array}{l}\text { New } \\
\text { Hampshire }\end{array}$ & State-level & $\begin{array}{l}\text { New } \\
\text { Hampshire Site } \\
\text { Evaluation } \\
\text { Committee }\end{array}$ & $\begin{array}{l}\text { Condition of approval } \\
\text { to a Certificate of Site } \\
\text { and Facility } \\
\text { Application }\end{array}$ & $\begin{array}{l}\text { In New Hampshire, as a } \\
\text { condition of approval for a } \\
\text { Certificate of Site and } \\
\text { Facility Application, the } \\
\text { owner of an energy facility } \\
\text { larger than } 30 \text { MW must } \\
\text { submit a decommissioning } \\
\text { plan and proof of financial } \\
\text { assurance to the New } \\
\text { Hampshire Site Evaluation }\end{array}$ & Yes & Yes & Yes \\
\hline
\end{tabular}




\begin{tabular}{|c|c|c|c|c|c|c|c|}
\hline Jurisdiction & Policy Type & $\begin{array}{l}\text { Oversight } \\
\text { Authority }\end{array}$ & $\begin{array}{l}\text { Relationship to } \\
\text { Programs, } \\
\text { Certificates, } \\
\text { Permits, or Other } \\
\text { Approvals }\end{array}$ & $\begin{array}{l}\text { Summary of } \\
\text { Requirements }\end{array}$ & $\begin{array}{l}\text { Decommissioning } \\
\text { Plan Required by } \\
\text { Regulations }\end{array}$ & $\begin{array}{l}\text { Financial } \\
\text { Assurance } \\
\text { Required by } \\
\text { Regulations }\end{array}$ & $\begin{array}{l}\text { Cost } \\
\text { Estimate } \\
\text { Required by } \\
\text { Regulations }\end{array}$ \\
\hline & & & & $\begin{array}{l}\text { Committee prior to } \\
\text { construction of the facility } \\
\text { (N.H. Rev. Stat. Ann. § 162- } \\
\text { H:2, 7). }\end{array}$ & & & \\
\hline North Dakota & State-level & $\begin{array}{l}\text { North Dakota } \\
\text { Public Service } \\
\text { Commission }\end{array}$ & $\mathrm{N} / \mathrm{A}$ & $\begin{array}{l}\text { In North Dakota, as a } \\
\text { condition of approval for a } \\
\text { Certificate of Operation, the } \\
\text { owner of a facility with a } \\
\text { capacity of } 500 \text { kilowatts } \\
\text { (kW) or greater must submit } \\
\text { a decommissioning plan } \\
\text { and proof of financial } \\
\text { assurance to the North } \\
\text { Dakota Public Service } \\
\text { Commission prior to the } \\
\text { operation of the facility } \\
\text { (N.D. Admin. Code } \S 69-09- \\
\text { 10-01, 06). }\end{array}$ & Yes & Yes & Yes \\
\hline Oklahoma & $\begin{array}{l}\text { Hybrid } \\
\text { state/local }\end{array}$ & $\begin{array}{l}\text { Delegated to } \\
\text { local } \\
\text { government }\end{array}$ & $\begin{array}{l}\text { An owner of a solar } \\
\text { energy facility subject } \\
\text { to a solar easement } \\
\text { is required to submit } \\
\text { a description of } \\
\text { decommissioning } \\
\text { plans that address } \\
\text { any local } \\
\text { regulations/requireme } \\
\text { nts. }\end{array}$ & $\begin{array}{l}\text { In Oklahoma, a solar energy } \\
\text { conversion system owner } \\
\text { who executes a solar } \\
\text { agreement (e.g., easement) } \\
\text { to secure a land right for a } \\
\text { solar energy conversion } \\
\text { system must include within } \\
\text { the solar agreement } \\
\text { instrument, a description of } \\
\text { any decommissioning plans } \\
\text { or financial assurance } \\
\text { instruments required by the } \\
\text { local jurisdiction where the } \\
\text { energy facility is located } \\
\text { (Okla. Stat. tit. } 60, \S 820.1 \text { ). }\end{array}$ & $\begin{array}{l}\text { No; check local } \\
\text { ordinances }\end{array}$ & $\begin{array}{l}\text { No; check } \\
\text { local } \\
\text { ordinances }\end{array}$ & $\begin{array}{l}\text { No; check } \\
\text { local } \\
\text { ordinances }\end{array}$ \\
\hline
\end{tabular}




\begin{tabular}{|c|c|c|c|c|c|c|c|}
\hline Jurisdiction & Policy Type & $\begin{array}{l}\text { Oversight } \\
\text { Authority }\end{array}$ & $\begin{array}{l}\text { Relationship to } \\
\text { Programs, } \\
\text { Certificates, } \\
\text { Permits, or Other } \\
\text { Approvals }\end{array}$ & $\begin{array}{l}\text { Summary of } \\
\text { Requirements }\end{array}$ & $\begin{array}{l}\text { Decommissioning } \\
\text { Plan Required by } \\
\text { Regulations }\end{array}$ & $\begin{array}{l}\text { Financial } \\
\text { Assurance } \\
\text { Required by } \\
\text { Regulations }\end{array}$ & $\begin{array}{l}\text { Cost } \\
\text { Estimate } \\
\text { Required by } \\
\text { Regulations }\end{array}$ \\
\hline Vermont & State-level & $\begin{array}{l}\text { Vermont Public } \\
\text { Utility } \\
\text { Commission }\end{array}$ & $\begin{array}{l}\text { Condition of approval } \\
\text { for Certificate of } \\
\text { Public Good. }\end{array}$ & $\begin{array}{l}\text { In Vermont, as a condition } \\
\text { of approval for a Certificate } \\
\text { of Public Good, the owner } \\
\text { of a facility with a capacity } \\
\text { of greater than } 500 \mathrm{~kW} \\
\text { must submit a } \\
\text { decommissioning plan and } \\
\text { financial assurance to the } \\
\text { Vermont PUC prior to } \\
\text { construction (30 V.S.A. } \S \\
\text { 248; Vt. PUC Rule 5.904). }\end{array}$ & Yes & Yes & Yes \\
\hline Virginia & $\begin{array}{l}\text { Hybrid } \\
\text { state/local }\end{array}$ & $\begin{array}{l}\text { Delegated to } \\
\text { local } \\
\text { government }\end{array}$ & $\begin{array}{l}\text { Condition of approval } \\
\text { for any local } \\
\text { government granted } \\
\text { solar facility site } \\
\text { license }\end{array}$ & $\begin{array}{l}\text { In Virginia, the state } \\
\text { legislature mandates that } \\
\text { local governments with } \\
\text { solar facility siting } \\
\text { ordinances include } \\
\text { decommissioning } \\
\text { requirements within their } \\
\text { regulations. Local } \\
\text { governments must require } \\
\text { owners of solar energy } \\
\text { equipment, facilities, or } \\
\text { devices owners to submit } \\
\text { decommissioning plans and } \\
\text { proof of financial assurance } \\
\text { to the local entity with } \\
\text { jurisdiction }(V a \text {. Code Ann. } \\
\text { §15.2-2241.2; Va. Admin. } \\
\text { Code } § 67-103)\end{array}$ & Yes & Yes & Yes \\
\hline
\end{tabular}




\begin{tabular}{|c|c|c|c|c|c|c|c|}
\hline Jurisdiction & Policy Type & $\begin{array}{l}\text { Oversight } \\
\text { Authority }\end{array}$ & $\begin{array}{l}\text { Relationship to } \\
\text { Programs, } \\
\text { Certificates, } \\
\text { Permits, or Other } \\
\text { Approvals }\end{array}$ & $\begin{array}{l}\text { Summary of } \\
\text { Requirements }\end{array}$ & $\begin{array}{l}\text { Decommissioning } \\
\text { Plan Required by } \\
\text { Regulations }\end{array}$ & $\begin{array}{l}\text { Financial } \\
\text { Assurance } \\
\text { Required by } \\
\text { Regulations }\end{array}$ & $\begin{array}{l}\text { Cost } \\
\text { Estimate } \\
\text { Required by } \\
\text { Regulations }\end{array}$ \\
\hline Washington & $\begin{array}{l}\text { State- } \\
\text { level/optional }\end{array}$ & $\begin{array}{l}\text { State of } \\
\text { Washington } \\
\text { Energy Facility } \\
\text { Site Evaluation } \\
\text { Council }\end{array}$ & $\begin{array}{l}\text { Condition of approval } \\
\text { for a certificate from } \\
\text { the Energy Facility } \\
\text { Site Evaluation } \\
\text { Council in lieu of any } \\
\text { other state permitting } \\
\text { requirements/approv } \\
\text { als }\end{array}$ & $\begin{array}{l}\text { In Washington, as a } \\
\text { condition of approval for an } \\
\text { optional certification } \\
\text { program, an energy facility } \\
\text { owner must submit a site } \\
\text { restoration plan and } \\
\text { financial assurance to the } \\
\text { energy facility site } \\
\text { evaluation council prior to } \\
\text { construction. }\end{array}$ & Yes & Yes & No \\
\hline Wyoming & $\begin{array}{l}\text { State/local } \\
\text { hybrid }\end{array}$ & $\begin{array}{l}\text { County Board } \\
\text { of } \\
\text { Commissioners }\end{array}$ & $\begin{array}{l}\text { Condition of approval } \\
\text { for permit application } \\
\text { for a solar energy } \\
\text { facility larger than } \\
500 \mathrm{~kW}\end{array}$ & $\begin{array}{l}\text { In Wyoming, as a condition } \\
\text { of approval for an operating } \\
\text { permit, the owner of a solar } \\
\text { energy facility with a } \\
\text { capacity of greater than } 500 \\
\mathrm{~kW} \text { must submit a } \\
\text { decommissioning plan to } \\
\text { the county board of } \\
\text { commissioners that has } \\
\text { jurisdiction prior to } \\
\text { construction of the facility } \\
\text { (Wyo. Stat. Ann. §§ } 18-5- \\
501,18-5-503) \text {. }\end{array}$ & Yes & No & No \\
\hline
\end{tabular}




\section{A.2 Solar Projects with a BLM Right-of-Way}

Table A-2. Solar projects with a BLM Right-of-Way

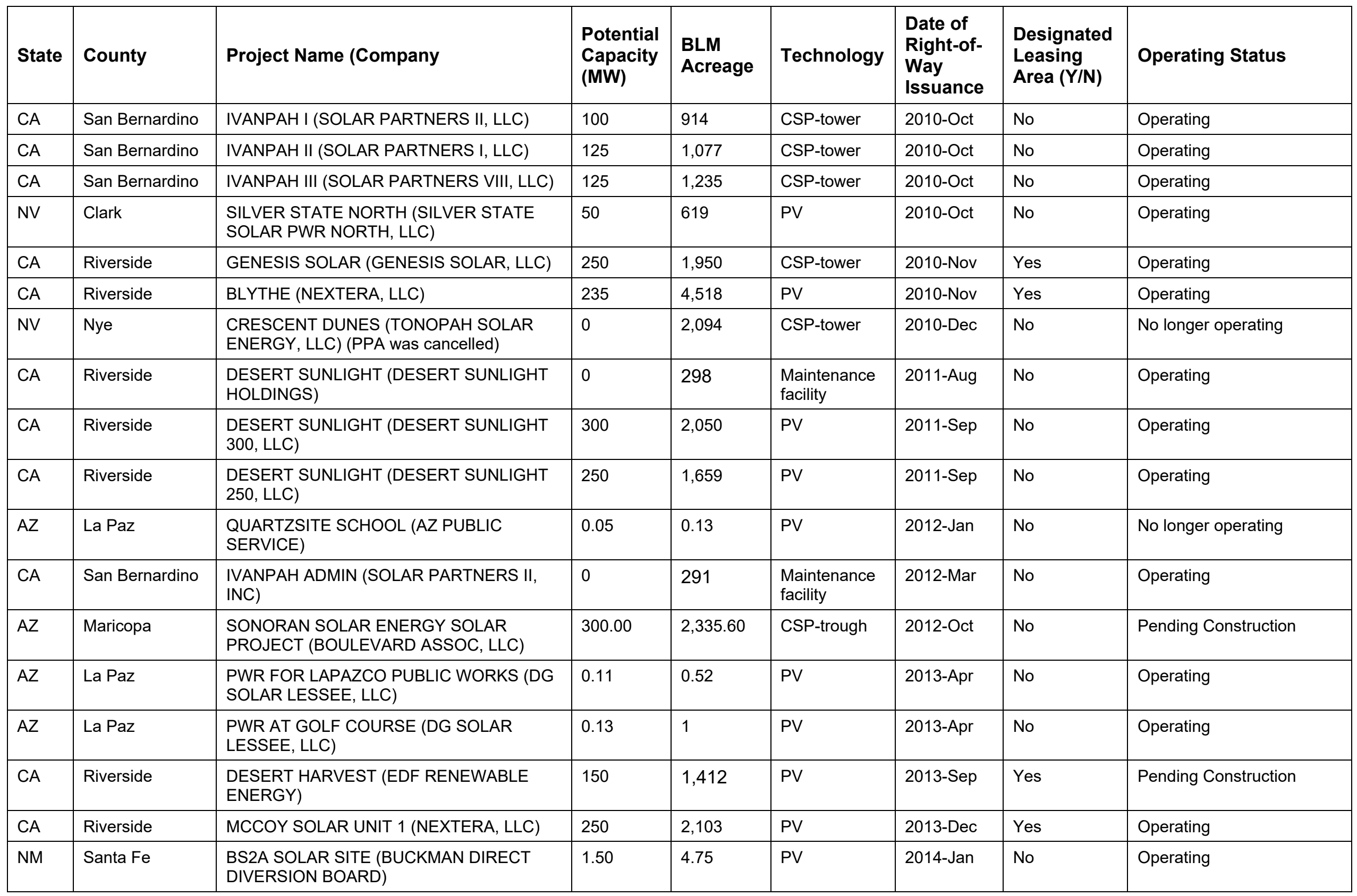




\begin{tabular}{|c|c|c|c|c|c|c|c|c|}
\hline State & County & Project Name (Company & $\begin{array}{l}\text { Potential } \\
\text { Capacity } \\
\text { (MW) }\end{array}$ & $\begin{array}{l}\text { BLM } \\
\text { Acreage }\end{array}$ & Technology & $\begin{array}{l}\text { Date of } \\
\text { Right-of- } \\
\text { Way } \\
\text { Issuance }\end{array}$ & $\begin{array}{l}\text { Designated } \\
\text { Leasing } \\
\text { Area }(\mathrm{Y} / \mathrm{N})\end{array}$ & Operating Status \\
\hline $\mathrm{CA}$ & San Bernardino & STATELINE (DESERT STATELINE, LLC) & 300 & 1,685 & PV & 2014-Mar & No & Operating \\
\hline NV & Clark & $\begin{array}{l}\text { SILVER STATE SOUTH (SILVER STATE } \\
\text { SOLAR PWR SOUTH) }\end{array}$ & 250 & 2,862 & PV & 2014-Jul & No & Operating \\
\hline $\mathrm{CA}$ & Riverside & $\begin{array}{l}\text { MCCOY SOLAR UNIT 2(NEXTERA, LLC) } \\
\text { (ARLINGTON) }\end{array}$ & 500 & 2,180 & PV & 2014-Aug & No & Pending Construction \\
\hline NV & Mineral & LUNING SOLAR (LUNING ENERGY, LLC) & 50 & 584 & PV & 2015-Jul & No & Operating \\
\hline NV & Clark & PLAYA SOLAR (PLAYA SOLAR II, LLC) & 79 & 1,062 & PV & 2015-Aug & Yes & Operating \\
\hline NV & Clark & $\begin{array}{l}\text { MOAPA SOLAR ENERGY CENTER (MSEC- } \\
\text { BIA) (EDF RENEWABLE ENERGY } \\
\text { DEVELOPMENT, INC. }\end{array}$ & 200 & 119 & PV - Gen-Tie & 2015-Aug & Yes & Pending Construction \\
\hline NV & Clark & PLAYA SOLAR (PLAYA SOLAR I, LLC) & 100 & 735 & PV & 2016-Aug & Yes & Operating \\
\hline NV & Clark & $\begin{array}{l}\text { HARRY ALLEN (HENRY ALLEN SOLAR, } \\
\text { LLC) }\end{array}$ & 130 & 640 & PV & 2018-Apr & Yes & Pending Construction \\
\hline WY & Sweetwater & $\begin{array}{l}\text { SWEETWATER SOLAR (SWEETWATER } \\
\text { SOLAR, LLC) }\end{array}$ & 80 & 584 & PV & 2018-Jul & No & Operating \\
\hline$A Z$ & Yuma & $\begin{array}{l}\text { PARKING FACILITY (SAN LUIS SPEAR } \\
\text { POINT SOLAR I, LLC) }\end{array}$ & 0.37 & 0.83 & PV & 2018-Nov & No & Operating \\
\hline $\mathrm{CA}$ & Riverside & PALEN (PALEN SOLAR, LLC) & 500 & 3,140 & PV & 2019-Mar & No & Pending Construction \\
\hline NV & Clark & $\begin{array}{l}\text { HARRY ALLEN SOLAR ENERGY CENTER } \\
\text { (INVENERGY) }\end{array}$ & 11 & 85 & PV & 2019-Nov & Yes & LNTP Request \\
\hline NV & Washoe & DODGE FLAT (NEXTERA) & 200 & 3,500 & PV & 2019-Nov & & Pending Construction \\
\hline NV & Clark & $\begin{array}{l}\text { DRY LAKE SOLAR ENERGY CENTER (NV } \\
\text { ENERGY) }\end{array}$ & 130 & 660 & PV & 2019-Dec & Yes & Pending Construction \\
\hline NV & Clark & $\begin{array}{l}\text { EAGLE SHADOW MOUNTAIN (BIA) (325MK } \\
8 M E, \text { LLC) }\end{array}$ & 420 & 144 & PV & 2020-Apr & & Pending Construction \\
\hline $\mathrm{CA}$ & Riverside & DESERT QUARTZITE, LLC & 600 & 2,673 & PV & 2020-Jul & Yes & Operating \\
\hline NV & Clark & GEMINI (ARIVA) & 690 & 7,063 & PV & 2020-Dec & & Limited NTP \\
\hline NV & Clark & YELLOW PINE (NEXTERA) & 500 & 2,987 & PV & 2021-Jan & & Pending Construction \\
\hline CA & Riverside & CRIMSON SOLAR & 350 & 2,489 & PV + Storage & 2021-May & Yes & Pending Construction \\
\hline
\end{tabular}

